\title{
HEIDEGGER ON TECHNOLOGY AND FREEDOM: THE PERILS OF HUMAN ESSENCE
}

By Cezary Gesikowski, B.SocSc., B.SocSc.Hon.

\author{
A thesis submitted to \\ the Faculty of Graduate Studies and Research \\ in partial fulfillment of \\ the requirements for the degree of \\ Master of Arts
}

Department of Political Science

Carleton University

Ottawa, Ontario

Canada

(c) Cezary Gesikowski 2005 


$\begin{array}{ll}\begin{array}{l}\text { Library and } \\ \text { Archives Canada }\end{array} & \begin{array}{l}\text { Bibliothèque et } \\ \text { Archives Canada }\end{array} \\ \begin{array}{l}\text { Published Heritage } \\ \text { Branch }\end{array} & \begin{array}{l}\text { Direction du } \\ \text { Patrimoine de l'édition }\end{array} \\ \begin{array}{l}\text { 395 Wellington Street } \\ \text { Ottawa ON K1A 0N4 } \\ \text { Canada }\end{array} & \begin{array}{l}\text { 395, rue Wellington } \\ \text { Ottawa ON K1A 0N4 } \\ \text { Canada }\end{array}\end{array}$

Your file Votre référence ISBN: 978-0-494-40600-7

Our file Notre référence

ISBN: 978-0-494-40600-7

NOTICE:

The author has granted a nonexclusive license allowing Library and Archives Canada to reproduce, publish, archive, preserve, conserve, communicate to the public by telecommunication or on the Internet, loan, distribute and sell theses worldwide, for commercial or noncommercial purposes, in microform, paper, electronic and/or any other formats.

The author retains copyright ownership and moral rights in this thesis. Neither the thesis nor substantial extracts from it may be printed or otherwise reproduced without the author's permission.
AVIS:

L'auteur a accordé une licence non exclusive permettant à la Bibliothèque et Archives Canada de reproduire, publier, archiver, sauvegarder, conserver, transmettre au public par télécommunication ou par l'Internet, prêter, distribuer et vendre des thèses partout dans le monde, à des fins commerciales ou autres, sur support microforme, papier, électronique et/ou autres formats.

L'auteur conserve la propriété du droit d'auteur et des droits moraux qui protège cette thèse. $\mathrm{Ni}$ la thèse ni des extraits substantiels de celle-ci ne doivent être imprimés ou autrement reproduits sans son autorisation.
In compliance with the Canadian Privacy Act some supporting forms may have been removed from this thesis.

While these forms may be included in the document page count, their removal does not represent any loss of content from the thesis.
Conformément à la loi canadienne sur la protection de la vie privée, quelques formulaires secondaires ont été enlevés de cette thèse.

Bien que ces formulaires aient inclus dans la pagination, il n'y aura aucun contenu manquant.

\section{Canada}




\section{TABLE OF CONTENTS}

\section{TABLE OF CONTENTS}

\section{ABSTRACT \\ INTRODUCTION \\ I CHALLENGE OF TECHNOLOGY}

1.1 The Purpose of Questioning Technology

1.2 In the Process of Questioning Technology

1.3 The Definition of Technology

1.4 The Dark Essence of Technology

1.5 Technology as a Continuous Challenge

\section{POSSIBILITY OF HUMAN FREEDOM}

2.1 Defining Freedom

2.2 Negative Freedom

2.3 Positive Freedom

2.4 Freedom as a Disclosure

2.5 Freedom of Thought, Speech, and Action

2.6 Mastering Freedom

2.7 Freedom as Letting-be

III LIBERTY IN TECHNOLOGICAL PERIL

3.1 Endangering Freedom

3.2 Masters of Delusions

3.3 Disposable Humans

3.4 Passionate Technophobes and Technophiles

3.5 Freedom from Technology 


\section{FREEING ESSENCE OF TECHNOLOGY}

4.1 Deliberate Contemplation

4.2 In This World, but Not of This World

4.3 Cultivating Openness to Mystery

4.4 Freeing Realm of Art

4.5 Piety of Astonishing Thought

CONCLUSION

WORK CITED 


\section{ABSTRACT}

The primary goal of this thesis is to show that Martin Heidegger establishes a strong link between technology and freedom. Specifically, to determine how his notion of the essence of technology, as Enframing-the destining spirit of the modern age-affects human freedom, as Dasein-our role in the revelation of Being. The introduction sets up the major points and briefly summarizes each of the chapters.

Chapter I examines Heidegger's definition of technology as well as his etymological and ontological study of Enframing. Chapter II presents Heidegger's discussion of freedom beyond the binary negative-positive formulation and the possibility of re-connecting humankind with the essence of Being. Chapter III scrutinizes the dangers Heidegger uncovers in the human quest for technological salvation, including alienation from Being, and subjugation of humans under Enframing as standing-reserve. Chapter IV analyzes the possibility of humanity achieving freedom by positioning itself in a proper relation to the essence of technology. According to Heidegger, this can be achieved by detachment from the essence of technology and cautious use of technological tools, as well as through contemplative thinking, questioning, and art.

The thesis concludes that Heidegger believes the essence of technology is not the destiny of humankind. While the danger of technology rests in the fact that it can deprive us of our freedom, it also carries a saving power that may emerge once we realize the consequences of blindly following the dictates of Enframing. Turning away from our destiny as Dasein may lead us into false convictions, complacency, and hubris resulting in slavery under the sway of Enframing. 


\section{INTRODUCTION}

Reflecting on the divergent perspectives of ancient and modern philosophy provides a unique insight into the forces that have shaped the outlooks and beliefs of humanity throughout time. For ancient philosophers, prudence, which is concerned with relations of limitation to possibility has been the basis of recognition of human limitations-Know Thyself, said the inscription above the entrance to the Delphic oracle's cave. Imprudence resulted largely from the violation of clearly-defined bounds. In contrast, modern philosophers see prudence as diligent preparation for future possibilities—Chance favors the prepared mind, proclaimed Louis Pasteur-imprudence became the consequence of being unprepared for circumstances that may come.

The relationship between thought (theoria) and action (praxis) reveals further disparity across history. Ancients drew a clear distinction between thought, traditionally the domain of philosophy, and action, the domain of politics. They believed thought without action was impotent, while action without thought resulted in blindness. The project of modern philosophy is to conflate thought and action, which results in technology. This is evidenced by modern revisions to the ancient understanding of causality. 
Aristotle, in Physics, lists four distinguishable causes (can you use a word other than "causes" here because of what follows): causa materialis, causa formalis, causa efficience, and causa finalis (or thelos). A modern account of causality appears in Hobbes' Leviathan collapsed into twofold structure. Causality one and three are conflated to generate a self-made man, while causality two and four are fused to create a man who determines his own purpose. This move compounds thought and action, making and knowing, techné and logos, to establish a forward-looking authority, the new messiah and savior of humanity—technology.

Technology appears to be ubiquitous and inevitable. It lightens our lives by ensuring greater efficiency and effectiveness. Technology is able to unlock and illuminate mysteries that have lingered concealed for millennia within the realm of sorcery, magic, and fantasy. Throughout history, humanity has been drawn toward alluring miracles. It has cultivated faith in the promises of myth, religion and, today, in science and technology-the latest offer of salvation under the command of reason. Each day technology unlocks a new secret, releases a new time saving device, or a better and faster way of completing chores. Humanity remains insatiable in its taste for novelty and amazement. The technological race is gaining momentum while leaving us with little opportunity to reflect on its meaning. Technological progress now seems automatic and is moving rapidly beyond 
the facility of individual human comprehension. There is a sense that we cannot stop the process.

As humanity collectively grows convinced that it is achieving more control over the planet, a question emerges in the shadows where the technological brand of enlightenment has not yet reached: does technology help us achieve freedom? With its promise of liberating humanity from the mundane errands of existence toward a greater freedom to pursue our desires, technology may, in fact, be locking us into a confined framework of technological thinking while, at the same time, eliminating non-technological alternatives to human understanding of being or reflection. Does technology lead us toward freedom or does it move us toward slavery? Are we even capable of identifying its direction? Are we in a position to change it by altering our relationship with technology?

Often, these questions are dismissed in contemporary political discourse as irrational fears, demagoguery of neo-Luddites, or as obstacles to technological progress. Who are these doubters corrupting the technological integrity of modern society? Before forcing them to mind their own business or treating them to a cup of hemlock, I summon the thoughts of their $20^{\text {th }}$ century spokesman.

This paper examines the link between technology and freedom in the writings of Martin Heidegger. Its aim is to determine how these concepts 
relate to one another and how they affect humanity. The author will examine Heidegger's deliberations on the essence of technology and freedom to argue that both of these concepts are linked strongly and form the foundation of Heidegger's unique understanding of Being while also shaping his opinion on the mission of humanity. It is also the goal of the author to determine whether Heidegger believes humanity can achieve a free relationship with technology and attain freedom through technological means, or whether he perceives technology as a danger that threatens the very existence of humankind.

The author will present a critical analysis of Heidegger's original writings, specifically The Question Concerning Technology and Other Essays, The Essence of Human Freedom-An Introduction to Philosophy, Martin Heidegger: Basic Writings, as well as secondary literature that examines Heidegger's writings and ideas by Richard Rojcewicz, Andrew Feenberg, Leslie Paul Thiele, Alan M. Olson, Julian Young, George Pattison, George Steiner, and Hannah Arendt, among others. The texts were selected on the basis of issue relevance, availability, and the latest developments in the study of technology and Heideggerian thought. The author recognizes that the chosen bibliography selected represents only a small cross-section of the volumes dedicated to the philosophy of technology and Heidegger's inquiry into the essence of Being. 
The first part of this thesis will focus on Heidegger's understanding of technology as well as his etymological and ontological consideration of what he calls the essence of technology that draws an important distinction between the understanding of ancient and modern technology. This part also contains an assessment of the premeditated strategy Heidegger employs to advance the discussion about technology from the passive, equipment-focused monologue of technical experts, toward a theoretical investigation based on open and attentive philosophical discourse that promotes debate.

The second part of this thesis will examine Heidegger's discussion of freedom. This will extend beyond the negative formulation of freedom from a constraint and positive freedom to attain to his thoughts about opening the human experience to the possibility of re-connecting with the essence of Being in the world. In addition, this section will explore the link between freedom and truth proposed by Heidegger as well as his understanding of freedom as a process that unfolds through time.

The third part of this thesis will scrutinize the dangers Heidegger sees stemming from the relentless pursuit of technological solutions to humanity's problems - the quest for technological salvation. The arguments in this section will investigate the risks of instrumental thinking of technology and the Enframing of humanity in subordinate relation to technology which, 
according to Heidegger, could lead toward total alienation of humans from their essence of being and transform humanity into a resource subjugated by the essence of technology.

The fourth part of this thesis will analyze Heidegger's opinion about the possibility of humanity achieving freedom by positioning itself in a proper relation to the essence of technology-an arrangement where human beings neither surrender in blind obedience to technology, nor automatically reject everything technological before exploring alternative approaches to its very essence.

No examination of Heidegger's ideas can be complete without considering the debate surrounding his work and political past. Comments range from a high regard for his contribution to the field of political thought to a vehement discrediting of them. Heidegger might be dismissed as a mystic who purposely overwhelmed with intimidating terminology to obfuscate his meaning. George Steiner, in Heidegger, summarizes the most severe criticisms about him: "[Heidegger's] writings are a thicket of impenetrable verbiage; the questions he poses are sham questions; the doctrines he puts forward are, so far as anything at all can be made of them, either false or trivial." (Steiner 52) This is a representative example of the kind of criticism leveled at Heidegger's thinking over the years. 
The author recognizes that an analysis of Heidegger's work also must acknowledge the controversy surrounding his collaboration with the German Nazi regime during World War II and his ensuing silence regarding this period in his life. The events surrounding Heidegger's political activity around that time might have had a remarkable influence on his work, yet a thorough biographical examination of Heideggerian thought extends beyond the scope and objective of this thesis.

The author will focus on Heidegger's ideas while maintaining a distance from the judgmental polemics and biographical criticisms. Although the controversies surrounding Heidegger's life and ideas may persist, his influence upon numerous subsequent thinkers in history of humanity will remain undeniable. 


\section{THE CHALLENGE OF TECHNOLOGY}

Technology occupied Heidegger throughout much of his professional life, especially toward the end, after he witnessed the consequences of the German implementation of the will to power under Nazism. The technological means of devastation perfected during World War II and the resulting atrocities against humanity and nature began to substantiate the earlier warnings of prophetic thinkers. Nietzsche, Marx, Kierkegaard and others heralded the rise of nihilistic human lordship over the planet. Their ideas foreshadowed the gas chambers and crematories of Auschwitz, and the horror of the instantaneous nuclear annihilation of Hiroshima and Nagasaki. Humans proved they had the technological capacity to effectively obliterate the species and devastate the entire planet in the process.

Absorbed all his life by the mystery of human existence, Heidegger focused on the force he felt was consuming the attention of humanitytechnology. In his post-war writings, and especially in The Question Concerning Technology and Other Essays, Heidegger identifies technology as the most significant problem of modernity. Although not the first to confront this issue, his investigation and methodological approach differed vastly from the observations offered by his contemporaries, as Andrew 
Feenberg explains in the following passage from Heidegger and Marcuse:

The Catastrophe and Redemption of History:

Most philosophers either celebrate technical progress or worry about its unintended consequences; they conceive society as separate from technology, which holds either a promise or a threat. Heidegger, on the contrary, defines modernity itself as the prevalence of technology. Particular technical achievements and failures are unimportant since our very dependence on technology gives rise to general catastrophe. (Feenberg 1)

Feenberg observes that Heidegger quickly came to the conclusion that the essence of technology was at the center of his investigation and that this essence had nothing to do with the tangible and predominantly instrumental technological manifestations that humans held in high esteem. For Heidegger, technological paraphernalia were mere mechanisms of a compelling yet imperceptible force that established subtle means to direct human essence into uncharted territory. Heidegger recognized this force as revealing, while at the same time obscuring the essence of Being. This force appeared to him as a dance between manifestation and concealment-a kind of theatrical production of a thousand veils pulled over the face of truth, which he was determined to expose.

Heidegger's writing style is very dense and employs challenging word play. His preoccupation with language and poetry often results in contradiction—while he aims at precision and clarity of his words, many 
readers experience difficulty in understanding what he means. This is exacerbated by the difficulties that inevitably stem from translations. However, his arguments are laid out in a very shrewd and straightforward fashion, achieving balance and flow. Despite being highly critical of limitations imposed by rational thinking and pragmatic linguistics, his explanations follow a logical pattern of convincing argumentation, even if his linguistic experiments sometimes bewilder human rationality. The Question Concerning Technology and Other Essays is a collection of texts comprising a self-reflective inquiry. It begins with a justification of Heidegger's motives for the investigation and, at the outset, repositions the technological discourse by employing a carefully-crafted methodology. Heidegger opens his argument by formulating a new definition of technology that taps into the etymological roots of ancient Greek. He develops a novel approach to dealing with the essence of technology: Heidegger moves the basic question about technology to a broader plane by extending it to the search for the essence of freedom rooted in the question of Being.

It is neither Heidegger's intention to provide definitive conclusions nor to simply stir our curiosity about the subject of technology. For him, technology is one of the most crucial and pivoting topics in the process of reflecting upon modern (and some may argue post-modern) currents shaping human understanding of consciousness and Being. However, his 
work appears to be incomplete, an argument in progress and it seems to raise more questions than offering answers. Despite the numerous years that have passed since he delivered the lecture on The Question Concerning Technology, the ideas from this text appear to be of as much relevance now, in the current socio-political context and its blunt manifestations of technological thinking and technologically-mediated perspectives on humanity.

This section of the thesis will examine Heidegger's beliefs regarding the purpose of questioning technology and the process he chose to investigate issues stemming from the dominance of technological thinking in our world. It will also explore Heidegger's grounding of the new definition of technology in what he identifies as its essence and look at the nature, as well as the influence, of this essence on humanity.

\subsection{The Purpose of Questioning Technology}

According to Babette Babich in The Essence of Questioning After Technology: Techne as Constraint and the Saving Power, Heidegger proposes a phenomenology of motive questioning in response to "the contemporary expression of technology [that] condemns questioning to nothing more than a calculative convention (namely that of question and answer) rather than an open-ended or attentive project." (Babich 107) 
Babich also notes that calculative questioning seeks only to satisfy demand for information with correct answers, which resembles an interrogation following a predetermined direction, and is not the same as attentive questioning which "attends both to what is asked as what is asked about what is asked and listens to that which is sought by the question." (Babich 107) In addition, there is always more behind an attentive question than a search for an answer. Babich suggests the question of the question marks Heidegger's inquiry as a project extending beyond a mere hunt for an answer.

Rather, it opens a dimension of thinking that technological questioning has subjugated during the course of scientific-empirical expansion, as highlighted by Babich in the following passage:

If questioning has become insipid in the wake of technology or else in the placidity of the thoughtlessness of Western reason, we need to ask Heidegger's question once again. We do this not by questioning technology but by questioning questioning (sic.) in the wake of technology. (Babich 110)

It is a challenge to formulate attentive questions within rational precincts of contemporary language and thought. Heidegger has written extensively on both, revealing that numerous restrictions forced upon humanity are repercussions of technological thinking which tempers our experience of the world and prevents humanity from feeling at home in the world. 
Heidegger expands, at times poetically, the meaning of his message. He uses language that is often ambiguous and distracting, while at the same time forcing attentive reflection and intellectual engagement. A reader attempting to skim through Heidegger's texts will inevitably fail to appreciate the importance of the question of the question.

To ensure his intentions are not hijacked by calculative thinking, Heidegger focuses on building the reader's attentiveness by stressing that his "questioning builds a way" which is not a typical method of inquiry but instead "a way of thinking" and "all ways of thinking, more or less perceptibly, lead through language in a manner that is extraordinary." (Heidegger, "The Question Concerning Technology" 3) This is to say that his writing is not a traditional inquisitive discourse, but a literary manifestation of thought crafted to convey an important message while approaching the limits of human understanding and which, at times, pushes beyond the comfort zone of contemporary readers. While Heidegger's extraordinary language does not stretch the boundaries of comprehension as far as James Joyce in Ulysses or Finnegan's Wake, most passages in The Question Concerning Technology and Other Essays, The Essence of Freedom, and Basic Writings demand the highest attention and reflection. The process of inquiry is, for Heidegger, much more than a purely intellectual exercise. He seeks to extract meaning from the process of asking questions without always expecting answers. "If we inquire, step by 
step, into what technology ... actually is, then we shall arrive at revealing," claims Heidegger, adding that this process will bring us to a new level of understanding: "another whole realm for the essence of technology will open itself up to us. It is the realm of revealing, i.e., of truth." (Heidegger, "The Question Concerning Technology" 12) With this statement a new dimension emerges in the examination of technology undertaken by Heidegger. He appears to be taking a turn toward a humanistic approach in his inquiry. However, Rojcewicz, in his book The Gods and Technology, claims there is nothing of the usual humanism in this philosophy, as he illustrates in the following passage:

For Heidegger, there is something which holds sway over humans, is more eminent, more autonomous, and it would be utterly parochial to regard humans as the prime movers. This applies especially to that most decisive of all accomplishments, the disclosure of truth. To consider humans the agents of truth, to consider truth a primary human accomplishment, would amount to hubris, a challenging of the gods, and would draw down an inexorable nemesis. (Rojcewicz 3)

Heidegger cautions his readers and gives them instructions on how to approach this difficult subject. The complexity of inquiry into technology weaves a web of references across past and current questions of how we live, and how we ought to live. For Heidegger, how we should live remains a question that demands constant and incessant asking. He offers help on 
following his arguments while accompanying him in the discovery of a proper way of relating to technology.

\subsection{In the Process of Questioning Technology}

In The Question Concerning Technology, Heidegger begins by instructing the reader that the process of this inquiry is as important as its findings; that every step of his argument, every single sentence and topic, carry almost as much weight as the whole argument. He proposes a way of thinking "through language in a manner that is extraordinary" (Heidegger, "The Question Concerning Technology" 3) and outside the realm of usual understanding. He hints at the poetic awe that bewilders and challenges stale thinking established by our contemporary "convenience culture where everything is laid on for us to such an extent that we are not even aware of the infinitesimal level of networking and organization which keeps the entire system afloat." (O'Brien 4) Heidegger wants to wrestle thinking away from the formulaic process and establish an open and receptive rapport with his readers, which is the first step toward changing the process of thinking necessary to understand his message--though he realizes that not everyone will be capable of appreciating his experimentation. He deliberately uses language to ensure the clearest reception of his arguments and intentions, as illustrated in the following passage: 
We shall be questioning concerning technology, and in so doing we should like to prepare a free relationship to it. The relationship will be free if it opens our human existence to the essence of technology. When we can respond to this essence, we shall be able to experience the technological within its own bounds. (Heidegger, "The Question Concerning Technology" 3-4)

It is here that he establishes the foundation for his entire argument about technology. Heidegger's approach is about thinking about technology as experiencing rather than cognition alone, which is a major departure from the view of the day. He claims that technology, as it is commonly understood, is not the essence of technology that he intends to investigate in the unfolding argument.

In The Question Concerning Technology Heidegger hoped to redirect the discussion of technology away from the technical experts to a historical discussion of the issue. To do this, he employed an ontological critique engaging etymological analysis of technology "in order to come up with an appropriate name for our contemporary 'mode of thinking,"' (Thomson 53) which reaches beyond the common understanding of technology.

Heidegger's approach relies on attempting to establish new ground rules for the process of inquiry into technology. However, this approach is complicated by the fact that Heidegger uses a very florid and nearly poetic style of writing that is often abstract and obfuscating. As Feenberg notes 
"Heidegger's philosophy of technology is a puzzling combination of romantic nostalgia for an idealized image of antiquity and deep insight into modernity" but he recognizes that it also offers a unique approach "treating technique not merely as a functional means but as a mode of 'revealing' through which a 'world' is shaped. 'World' in Heidegger refers not to the sum of existent things but to an ordered and meaningful structure of experience." (Feenberg 2) This structure relies on historical chance of an open forum where Being could be revealed, adds Feenberg. Such forum could be achieved through a language dedicated to thoughtful inquiry, not simply questioning to achieve answers. This type of attentive and open investigation of truth would allow Being to reveal itself.

It is important to recognize that, for Heidegger, questioning is of far greater importance than the search for an answer, because questioning opens the possibility of finding something greater than an answer. Rojewicz notes that "for Heidegger, the human powers of disclosure are indeed appropriated by something ascendant over them, something which discloses itself to humans-or which hesitates to do so," thus even most attentive and careful search for truth is doomed to failure at the outset since "the truth has drawn over itself a more impenetrable veil." (Rojcewicz 5) A question emerges: what is this veil? What is it made of? Why is it determined to draw truth deeper into concealment? One possibility is that the veil is language that has fallen under the influence of technological 
thinking. Since language is the principal method of formulation and dissemination of knowledge and understanding among humans, its importance in the shaping of human world is inestimable.

Heidegger uses linguistic and etymological analysis of language to determine how technology is understood in the contemporary mindset. It is in speech that superficiality emerges, according to Heidegger, but not because of a lack of effort by humans to push language constantly beyond its limits (i.e., the constant rapid expansion of technical vocabulary relating to computer and information technology). Neither is it because humans have "overlooked Being," Rojcewicz suggests, but rather quite possibly because "Being has become increasing reticent in showing itself." (Rojcewicz 5) As a result, the immense effort of human struggle to reconnect with Being is hampered by the pursuit of technology at all cost. This throws into doubt the ability of humanity to understand technology and to comprehend technological consequences on the nature of human existence within the historical perspective of disclosure of Being. Prior to commencing a deeper study of the issue, Heidegger defines his understanding of technology. 


\subsection{The Definition of Technology}

Searching for a definition is a process. It is as much a quest for the nature of a thing as for linguistic precision and exactitude. "Heidegger believes that we need to understand the correct or standard definition of technology before we can grasp the 'true' definition of technology." (Godzinsky 3) Heidegger recognizes the accuracy of the two standard definitions of instrumental technology, one as "means to an end" and the other as a "human activity." (Heidegger, "The Question Concerning Technology" 4) In Heidegger's opinion they belong together and are valid, yet he argues that the instrumental definition of technology is not sufficient and does not allow a deeper investigation of technology from the ontological perspective aiming to reveal its metaphysical origins. In order to discover "the true definition of technology ... Heidegger says that we must understand modern technology from a different perspective that is not constituted by straight-line instrumentalism." (Godzinsky 3 ) Heidegger opens the discussion to a historical investigation of the origins of technology by careful consideration of the etymological source of the word used today to describe a wide range of phenomena. He is very conscious of the concealing aspects in usage of the word technology that is deteriorating into a vast generalization of many human activities involving merely a hint of technical facility. 
Determined to disclose the idiosyncrasy of the word, Heidegger investigated the genesis of the definition of technology to arrive at its Greek origins in Technikon, which is part of techné, and by that measure also an element of poiesis-the epitome of human language as manifested in poetry. (Heidegger, "The Question Concerning Technology" 12-13) Expanding upon Heidegger's ancient references, Darby summarizes the etymological analysis in the following passage:

Technology is a compound of the two Greek words techné and logos. Techné pertains to making and logos to knowing, to practices and to perceptions. But technology is not a compound in word only, for it is compounded from the copenetration of making and knowing. Technology is the progressively rational (efficient) arrangement of means and ends (for humans) and cause and effect (for nature). The former, therefore, has to do with practices, and the latter with perceptions. (Darby 52)

The impact of the etymological deconstruction of this compound word reveals that technology not only determines what we do in the world but also how we define ourselves in relation to nature and what we construe as our role in the world. This goes to the heart of the existential problems humanity has investigated throughout history. However, to see the full scope of historical importance, Heidegger presents the concept of technology in history understood as a timeless development of human thought instead of a linear chronology of events. 
To elucidate his argument, Heidegger makes a clear distinction between ancient and modern technology. Although both are forms of revealing and unconcealment, the former concerns a commitment involving human stewardship of nature in "taking care of" and "maintaining" while the latter has emerged as a manipulation process that sets upon nature "in the sense of challenging it." (Heidegger, "The Question Concerning Technology" 14-15) Expanding upon this line of argument, Heidegger drafts a description of modern technology using "a long list of unmistakably pejorative, violent, imperious terms" which range from "a challenging, forcing, ravishing, attacking, throttling, dominating, exploiting, imposing, disposing, exposing, and deposing," and while stopping short of rape, his words "describe a violation of nature equivalent to rape." (Rojcewicz 71)

The greatest discrepancy between ancient and modern technology, argues Rojcewicz, is the use of violence, where imposing modern technology viciously demands Being to reveal itself and fall under the power of human will. Reaching beyond the violence of technological tools, Heidegger considers the fundamental nature of technology to discover the origins of technological violence. He claims to be most interested not in technology itself, but in the essence of technology, which he declares "is by no means anything technological" and difficult for humans to grasp, as "we shall never experience our relationship to the essence of technology so long as we merely conceive and push forward the technological, put up with 
it, or evade it." (Heidegger, "The Question Concerning Technology" 4)

Heidegger insists that the exercise is worth our attention, even if a solution does not appear as a clear possibility, because for Heidegger the process of questioning is superior to any conclusion.

Guiding the discussion along the historical and etymological path produces an ontological argument that is riddled with challenges. For some scholars, Heidegger's attempt to coin a new definition of technology that focuses on its essence is seen as an experiment in the art of the absurd. Thomson observes that Heidegger's explanation of the essence of technology as nothing technological resembles Wittgenstein's paradox of the measure where "height is not high, treeness is not itself a tree" and where "that which defines the measure cannot be measured meaningfully by the metric it defines." On the other hand, Thomson argues that Heidegger is purposely avoiding defining the essence of technology. (Thomson 52) This is done to circumvent the interpretation of essence in Platonic understanding as that which permanently endures, explains Thomson, and "once we conceive of 'essence as a verb rather than a noun, we can see that 'the essence of technology' denotes the way technological entities tend to 'come to presence' or happen for us." (Thomson 53) Thomson believes this allows Heidegger to introduce "the essence of technology [as] our current constellation of historical intelligibility, 'Enframing' (das Gestell), an historical 'mode of revealing' in which things 
increasingly show up only as resources to be optimized." (Thomson 53) With a solid definition of the main issue of his investigation, Heidegger begins to build a strong case for Ge-stell, choosing to hyphenate the word to emphasize its etymological significance. For Heidegger, Ge-stell expresses the essence of technology and explicitly manifests the chief characteristic underlying modern technology.

\subsection{The Dark Essence of Technology}

Abandonment of the instrumental definition of technology allowed Heidegger to consider deeper implications and historical roots of the essence of technology, which he believed manifested itself as Enframingthe process of enclosing human understanding within set horizons of technological thinking. When Heidegger succeeded in removing the spotlight from the importance of tools, the focus of the investigation into technology shifted toward understanding of Being within the context of technological artificiality. As Schirmacher argues in The Question Concerning Heidegger's Critique of Subjectivity, Heidegger developed a "realization that artificiality is the nature of man, and that technology, in all its so uncommonly diverse forms, is the realized, cosmic mode of being peculiar to our nature and which must be further perfected."

(Schirmacher 10) This original ontological perspective allowed Heidegger to 
consider early interpretations of technology before drawing any supposition about the contemporary condition of modern technology. As earlier mentioned, Heidegger's ontological approach to the investigation of technology placed his arguments under very close scrutiny and criticism.

The strategy to liberate the debate on technology from technical experts required a solid footing for the argumentation that Heidegger proposed. This is perhaps why he decided to turn toward the subject of his expertise - the history of ancient Greek philosophy—and drew on the etymological roots of technology. This approach also allowed him to demonstrate a historical perspective to illustrate a clear distinction between ancient and modern technology, which he used in the close analysis of the latter. Here Heidegger's contribution to the study of technology is most evident. His etymological insight was valuable in the establishment of a new definition of technology and a completely new perspective on the role of technology within the efforts of humanity that was aiming to define itself in the context of the universe.

Through contemplations on ancient understanding of technology, Heidegger came to understand that techné is a form of revealing and is part of poeisis, as illustrated by Thiele in the following passage from Timely Meditations: Martin Heidegger and Postmodern Politics:

Reflecting on the ancient Greeks, Heidegger notes that the root of the word 'technology' is techné, which signifies not so much the 
making of something as its production in an etymologically strict sense: its leading or drawing forth. For the Greeks, techné signified a revelation of something, its uncovering or bringing to light. (Thiele 195)

The ancient pedigree of technology reveals the human quest for understanding. From the earliest time, humans searched by gazing into the essence of the world around them to discover truth. Heidegger argues that technology is an extension of this quest since it is also "a mode of revealing" that "comes to presence in the realm where revealing and unconcealment take place, where alethia, truth, happens." (Heidegger, "The Question Concerning Technology" 13) Schirmacher notes that technology is, in many respects, a "human way of responding to the universe" (Schirmacher 10), which is different under the ancient definition of technology and the way modern technology responds to the revelation of truth-to the disclosure of Being in the world.

For Heidegger the revelation of Being by ancient technology was "an affair of looking disclosively upon Being or upon the essence of things." (Rojcewicz 67) However, modern technology can no longer be described in those terms. The difference between these two is not simply in the dissimilar instruments they used for the interaction with the real world. There is a disagreement between these two approaches in the mode of revelation of Being, where Heidegger argues "modern technical thinking assumes that it grasps Being, ... but in actuality it fixes reality [or Being] as 
a constancy and objectivity that can be ordered, and so misses Being itself." (Rickey 151) Wrongly convinced of its proper understanding of Being, modern technology challenges nature and perceives it as standingreserve, a warehouse of resources ready to be used at whim, for any imaginable purpose, without any consideration or care, and without bearing in mind the possible consequences.

It is important to note that modern technology contains some elements of the ancient technology and thus emerges as a duality-it challenges and reveals at the same time, as Godzinsky notes in the following passage from [En]Framing Heidegger's Philosophy of Technology:

On one hand, Heidegger sees modern technology as a 'challenging.' As a challenging, modern technology 'puts to nature the unreasonable demand that it supply energy that can be extracted and stored as such.' On the other hand, Heidegger also views modern technology as a form of revealing. Accordingly, in and through its revealing, modern technology has a tendency to unlock, transform, store, and distribute the resources that nature has to offer. (Godzinsky 3)

This quality of modern technology contains a great potential and a great threat. The opening and revealing of resources creates opportunities for people to further their well-being and to make them more comfortable in the world by mitigating harsh natural elements or by manipulating nature to their advantage. At the same time, the consequences of unreasonable demands put upon nature can be devastating and ultimately lead to demise 
of humanity. Rojcewicz notes that "ancient technology looked upon things in general as nature of the original Greek sense of what is growing, selfemerging, pregnant." However, for Heidegger, modern technology expresses the greatest possible contrast by being utterly "disrespectful; it looks upon things as disposable and proceeds to turn them even more manifestly into disposables." (Rojcewicz 125) What is most crucial, is that Heidegger believes the greatest danger lies in the essence of technology manifesting itself through Enframing, not in the power of instant selfannihilation that technology has given humanity, nor in the wasteful and devastating consequences from the application of modern technology.

Thus Enframing poses the most challenging claim of modern technology. According to Thomson in Heidegger on Technology: Ontology and the Politics of Education, Heidegger finds roots for his ontological critique of Enframing in the Kantian idea that "we implicitly participate in the making-intelligible our world, but [Heidegger] maintains that our sense of reality is mediated by lenses inherited from metaphysics." (Thomson 53) Consequently, argues Thomson, Heidegger developed a historical context for "Kant's 'discursivity thesis' which holds that intelligibility is the product of a subconscious process by which we 'spontaneously' organize and so filter a sensibly overwhelming world to which we are fundamentally 'receptive."' (Thomson 53-54) This filtering process is entrenched within human consciousness and positions itself as the only viable form of understanding 
of the world. It prevents us from becoming overwhelmed by the world, but Heidegger warns that it also carries a grave threat.

This threat is not clearly evident as it hides in the shadows of technological gifts. While posing danger, Enframing also contains a saving power. To illustrate this poetically Heidegger turns to Hölderin's verse:

But where danger is, grows

The saving power also

(Heidegger, "The Question Concerning Technology" 28)

With Hölderin's words, Heidegger declares he is judging technology neither as something intrinsically evil nor as something inherently good, but rather, he insists, technology is both of these at the same time. It is important to note that it is not something beyond good and evil. For Heidegger it demands an ongoing investigation involving proper and attentive questioning that engages a historical view extending even beyond the scope of Heidegger's own inquiry.

\subsection{Technology as a Continuous Challenge}

The essence of technology, according to Heidegger, remains Enframing - the incessant exploitation of resources, measuring and organizing of everything in the realm of human consciousness. But he also recognizes that modern technology offers seemingly infinite possibilities for humanity, including the chance of human freedom unimaginable before the 
arrival of instrumental technology, which reveals the limiting consequences of technological thinking. Heidegger's investigation into the essence of technology does not offer a set of ready-made solutions for he never claims technology is a problem to be solved, rather that the process of inquiry aims to awaken further questions within the reader. This effect is a deliberate step in Heidegger's presentation that searches for the essence of technology within the realm of art, filled with mysteries and questions, as illustrated in the following passage:

Thus questioning, we bear witness to the crisis that in our sheer preoccupation with technology we do not yet experience the coming to presence of technology, that in our sheer aesthetic mindedness we no longer guard and preserve the coming to presence of art. Yet the more questioningly we ponder the essence of technology, the more mysterious the essence of art becomes. ... For questioning is the piety of thought. (Heidegger, "The Question Concerning Technology" 35)

Why did Heidegger consider questioning to be of the highest value? Rojcewicz points out that Heidegger saw humans as Dasein-the midwives "to the self revelation of Being" in the world. (Rojcewicz 7) Heidegger suggests questioning is of the utmost importance because if we continue to question we remain true to our destiny as Dasein and thus continue on a path toward freedom. A careful study of freedom, as outlined in the next section, assisted Heidegger in his reflections on the essence of technology and its effect on human perception of the world, reality, and truth,. 


\section{POSSIBILITY OF FREEDOM}

Freedom is a uniquely human concern. Throughout time, humans often have placed freedom before their instinct to survive. This is what distinguishes them from every other species on the planet. Freedom also is a controversial issue fuelling volatile debates and bloody schemes, from pre-Socratic philosophers discussing the wrath of gods, to the post-9/11 strategists struggling to rescue the world from the clutches of suicidal zealots. There are innumerable volumes proposing theories of what constitutes freedom and how freedom can be attained, sustained, or destroyed, yet freedom remains ineffable.

For Heidegger, "the question concerning the essence of freedom is the fundamental problem of philosophy, even if the leading question thereof consists in the question of being." (Heidegger, "The Essence of Human Freedom" 205) Yet Heidegger is rarely identified as a philosopher concerned deeply with the concept of freedom. This could be due to his controversial political past. To launch an inquiry into freedom through Heidegger's lens immediately raises concerns over his association with the German Social Nationalist party in the 1930s. "For many, Heidegger's prerogative to investigate freedom should be irreversibly revoked," observes Thiele, "because of his fervent support of the National Socialism while servicing as rector of Freiburg university and his subsequent 
reluctance to atone for or even come to terms with the significance of his involvement." (Thiele 62) Heidegger's political past and its impact of on his philosophy continue to outrage and fascinate scholars. Although, he was not the first, nor doubtlessly the last, of philosophers who had experienced the shock of the difference between political theory and practice of politics. Just as Plato after his Syracuse fiasco, Heidegger plunged back into the current of philosophy and remained forever silent about that period of his life. As a result, a strong Nazi stigma remains concerning his writings and it discourages some from examining his ideas, particularly those on human freedom.

Besides his tainted political involvements, Heidegger is not seen as the leading philosopher of freedom due to his unique understanding of this phenomenon. Heidegger "articulates freedom in a way that takes us beyond traditional formulations-formulations of which he remains consistently critical" points out Thiele. As a result, his ideas on freedom and technology are often dismissed as "overly idiosyncratic and hence irrelevant to standard debates, or his perspective ... is held to leave little room for liberty of any ilk." (Thiele 62) To mitigate these limitations, Heidegger approaches technology and freedom from a unique vintage point with his own ontological discourse--through the lens of inquiry into the essence of Being. 
Traditionally freedom is understood in terms of positive, negative, and what might be called Foucaultian or Nitzschean liberty. These perspectives exhibit a shared attribute: they perceive freedom as a form of mastery. Heidegger offers an alternative, demonstrating an urgent need for rearticulating of what in the West we find most essential to our historical and political being. (Thiele 68) His shift in thinking about freedom abandons leading political theories that focus on group freedom and encourages understanding of freedom as an individual attribute guiding our political lives. It is not enough to be protected from the trespasses of others as proposed by the negative freedom, claims Heidegger, but neither is true freedom understood positively as the ability to be the most one can be. He believes that human freedom is possible only in our function as Dasein.

Heidegger insists that humans play the role of Dasein-the disclosers of truth-in the revelation of Being and, thus, they must strive to attain the appropriate awareness and understanding of this responsibility. Knowledge, like freedom, is not a subject for human possession, but rather it manifests itself as a process. Heidegger distills this concept of Dasein by elucidating the connection between knowledge as perception and the body. We perceive the world through sensual impressions that are dispersed throughout the body, but it is the soul that brings these individual perceptions together. Thus, knowledge and human Dasein are dependent upon a working together of body and soul. As the body is increasingly being 
replaced by technology_telephone, television, radar, x-ray machines, etc.-technology mediates the world and functions as a filter determining our interpretation of the world. This progressive disembodiment is what Heidegger fears will result in severing of the bond between humanity and Being, loss of our dignity as Dasein. He reflects on the irrevocable deterioration of our freedom caused by the growing dependence on technology.

This section of the thesis will examine Heidegger's definition of freedom contrasted against that of the mainstream philosophical approach to and analysis of the concept. The author will also examine the established perspectives of negative and positive freedom to indicate Heidegger's leaning historically, as well as his proposal to redefine freedom beyond the limitations of this binary approach. The inquiry in this section will turn toward the distinct aspects of freedom as a process aiming to uncover truth, as well as the implications on freedom on thought, speech, and action. The inquiry then will look at Heidegger's alternative-an unorthodox approach to freedom as openness to the mystery of Being. After grounding the discussion of freedom in the essence of Being, a deeper analysis of the distinctive link between freedom and technology will be undertaken. 


\subsection{Defining Freedom}

The highest type of free man should be sought where the highest resistance is constantly overcome: five steps from tyranny, close to the threshold of the danger of servitude. (Nietzsche, "Portable Nietzsche"542)

Freedom is understood commonly as an absence of restrictions, especially slavery, and power of self-determination. It also is understood in terms of a personal or political right to act and speak as one pleases without interference. (Barber 553) However, it is nearly impossible to define a concept taken out of its context, especially a concept as abstract as freedom. Therefore it is important to use precise language. Freedom should not be approached as "simply a subordinate or subsidiary concept, but one of the system's ruling centerpoints," observes Shelling in Philosophical Investigations into the Essence of Human Freedom and Matters Connected Therewith, yet "the concept of freedom is in fact said to be completely incompatible with system, and every philosophy making claim to unity and wholeness should end up with the denial of freedom." (Shelling 9) Throughout his investigation, Heidegger gives an impression of being disinterested with mainstream concepts of freedom.

In the Essence of Human Freedom, Heidegger approaches freedom as a topic that provides context "to understand philosophy in a positive way from itself" and avoid "empty discussion concerning philosophy in general." 
(Heidegger, "The Essence of Human Freedom" 14) Using Isaiah Berlin's distinction between negative and positive freedom, Heidegger establishes the traditional definition of freedom as "breaking free, casing of fetters, overcoming constrictive forces and powers." (Heidegger, "The Essence of Human Freedom" 15) Rather than tackling the traditional definition, he turns to Kant for arguments to support his view of defining freedom in terms of his investigation of the nature of Being.

Heidegger recognizes freedom more as the positive freedom of being true to the real nature of the human soul, rather than negative freedom characterized by striving for elimination of outside forces on the human ability to act. However, his understanding of positive freedom stands in opposition to Kant's idea of positive freedom as "self-determination", "absolute self-activity" and the "'power' of man to 'determine himself from himself." (Heidegger, "The Essence of Human Freedom" 15) The true power of human freedom, claims Heidegger, has nothing to do with the pursuit of mastery; rather it manifests itself as a form of caring for things, which enables humans to be the beings they are. "Heidegger's mysticism" argues Rickey "led him to embrace a new understanding of freedom as freedom for the revelation of being; in being free for Being, one participates in the meaning of existence given by the revelation." (Rickey 11) By limiting the spectrum of his inquiry, Heidegger succeeded in circumventing the 
orthodox concepts of freedom but not without drawing criticism from other thinkers.

Heidegger's definition of freedom attracted strong criticism from his long-time friend (turned philosophical nemesis) Karl Jaspers, points out Gorniak-Kocikowska. Jaspers declared this type of freedom was impossible, claiming that "human being is not free on the empirical plane nor in the sphere of transcendence" and while "only existential freedom is true freedom," he was convinced that "freedom itself does not reach transcendence." (Gorniak-Kocikowska 144) Jaspers expresses harsh disapproval by declaring that Heidegger is utterly ignorant of what freedom truly is. (Gorniak-Kocikowska 144) The philosophers never reconciled their differences. The definition of freedom remains open to philosophical discussion and debate today.

\subsection{Negative Freedom}

Heidegger recognizes that freedom is generally understood as independence from external restrictions and that its appeal stems from liberation from bondage. (Heidegger, "The Essence of Human Freedom"15) The archetypical tale of a chosen tribe breaking free from slavery and oppression to return home is one of the most powerful and inspiring narratives that has served the past two millennia as the emotional 
and spiritual barometer of the Western world. By entrenching itself in the human consciousness, this story provides a blueprint for modern political thought, and that, effectively, incorporates other eclectic beliefs, thus strengthening the negative view of freedom.

Negative libertarians, including John Stuart Mill, Bertrand de Jouvenel, and John Locke, were strong advocates of "an empirical, atomic self that achieves mastery over a private domain through the expression of will." (Thiele 69) Tomas Hobbes succinctly captured the negative understanding of human freedom as Jus Naturale characterized by "the absence of external Impediments: which ... may oft take away part of a man's power to do what he would; but cannot hinder him from using the power left him, according as his judgment, and reason shall dictate to him." (Hobbes 189) At its most basic, negative liberty is freedom from limitations enabling individuals to pursue their desires without hostility from others who may oppose their practices, beliefs, or voiced opinions.

The dominance of negative freedom is evident today and surfaces frequently in international debates about global security and protection of human rights. The contemporary definition of human freedom, in

its particularly modern formulation, teeming from the Renaissance and the Reformation, encompasses the notion of privacy, a sacrosanct area of personal freedom over which the individual has complete jurisdiction and which demands protection form all external interference, whichever by the church, the sate, or society. Negative 
liberty denotes the individual's unchallenged control over his or her (immediate) environment. (Thiele 63)

The concept of negative freedom appears too limiting for Heidegger. $\mathrm{He}$ seeks to move the philosophical discussion on freedom beyond conventional definitions. Turning to Kant, he finds an idea of freedom that is closer to his early insights from Being and Time, where Being plays a crucial role in the human path to freedom.

Through an analysis of Kant's discussion of causality, Heidegger notes that Kant explains freedom as 'the 'power of self determination,' and 'absolute self-activity,"' which does not contain "anything negative" and seems to describe "positive (more precisely, non-negative) freedom." (Heidegger, "The Essence of Human Freedom" 16) This leads Heidegger to further reconsideration.

\subsection{Positive Freedom}

Heidegger's dismissal of negative liberty seems to indicate his leaning toward recognition of positive liberty. He sees positive freedom expressed as movement "toward-which"' as well as "being free for..., being open for...," thus inviting the potential "to determine one's own action purely through oneself, to give to oneself the law for one's action." (Heidegger, "The Essence of Human Freedom" 15) In contrast to the negative concept of freedom from, Heidegger views positive liberty as implying a freedom to 
action, empowering humans toward an achievement of greatness, rather than simply sheltering them from the existing dependencies as expressed by negative liberty.

Positive liberty is not the ability to follow one's individual desires without any interference from others. Thiele notes that it is "what one should desire, unhindered by internal constraint such as irrational drives or delusions, weaknesses of character, false consciousness, or even shortsighted judgment." He explains further: "free will is only truly free when it actualizes the individual's 'objective' interests. Positive liberty necessitates both the discovery of one's real needs (end desires) and the capacity to see them fulfilled." (Thiele 63) The theory, however, does not always lend itself to reality. Heidegger's fervent support for the National Socialist ideals earned him an appointment in 1933 as the rector of Freiberg University. During Hitler's rapid rise to power, Heidegger criticized academic freedom as an inadequate manifestation of negative freedom and declared that the will of individuals should remain subordinate to the general will of the people voiced through the National Socialist party and the Führer. (Thiele 72) Despite subsequent denouncement of this statement and abandonment of support for positive liberty, Heidegger's credibility was undermined severely. A swift exit from the political scene in 1934 brought him back to the familiar planes of theoretical inquiry and philosophical contemplation. He eventually developed a novel perspective on freedom 
grounded in the works of Nietzsche, which positioned freedom as an active pursuit of human destiny in the role of Dasein-freedom to fulfill our destiny as the revealers of Being in the world.

\subsection{Freedom as a Disclosure}

Heidegger's thinking about freedom evolves through time. Once he denounces the possibility of positive or negative liberty as the true freedom, his inquiry turns away from the arguments connecting freedom in its essence to the will or, as proposed by Kant, to the causality of human willing. (Heidegger, "The Question Concerning Technology" 25) He examines the German word freedom and relates it to the German word the opening, which leads him to seek opening elements in the essence of freedom. The resulting argument conflates freedom and truth as Heidegger illustrates in the following passage:

Freedom [Freiheif] governs the open [Freie] in the sense of the cleared and lighted up, i.e., of the revealed. It is to the happening of revealing, i.e., of truth, that freedom stands in the closest and most intimate kinship. All revealing belongs within a harboring and a concealing. But that which frees-the mystery-is concealed and always concealing itself. All revealing comes out of the open, goes into the open, and brings into the open. The freedom of the open consists neither in unfettered arbitrariness nor in the constraint of mere laws. Freedom is that which conceals in a way that opens to light, in whose clearing there shimmers that veil that covers what 
comes to presence of all truth and lets the veil appear as what veils. Freedom is the realm of the destining that at any given time starts a revealing upon its way. (Heidegger, "The Question Concerning Technology" 25)

While this argument seems convincing, the linguistic link between similarly sounding German words renders the universal conflation of truth and freedom questionable. Unlike in his etymological deconstruction of the word technology, Heidegger avoids an in-depth analysis of the origins of these words in Greek or Latin, relying strictly on the arbitrary lyrical connection between two terms in his native tongue. The lukewarm lyrical substantiation of the claims he proposes in the above passage is hardly compelling.

Yet he remains convinced of the connection between truth and freedom, which eventually develops into a strong argument in his critical examination of modern technology. In his essay On the Essence of Truth, Heidegger argues unrelentingly that "the essence of truth reveals itself as freedom." (Heidegger, "Basic Writings" 127) He clearly undermines the validity of the common and readily acceptable understanding of freedom, arguing it is not "mere absence of constraint with respect to what we can or cannot do" nor "mere readiness for what is required and necessary (and so somehow a being)." (Heidegger, "Basic Writings" 126) Rather, he sees freedom as springing from the process unveiling the truth, which he attributes to the practice of disclosure that is an integral aspect of existence: 
Freedom is not merely what common sense is content to let pass under this name: the caprice, turning up occasionally in our choosing, of inclining in this or that direction. ... Ex-sistence, rooted in truth as freedom, is exposure to the disclosedness of beings as such. ... Prior to ... 'negative' and 'positive' freedom, freedom is engagement in the disclosure of beings as such. Disclosedness itself is conserved in ek-sistent engagement, through which the openness of the open region, i.e., the 'there' ['Da'], is what it is. (Heidegger, "Basic Writings" 126)

The association between existence and the necessity of disclosure is much more convincing that the linguistic leap of faith in the poetic association between Freiheit and Freie, yet is it strong enough to cement the freedom-truth relationship? Existence, even in its most crude meaning as the instinct for survival, requires a firm grasp of immediate reality, which necessitates a need for rudimentary knowledge and understanding of one's immediate environment. However, it would be a fallacy to diminish Heidegger's argument by attempting to fit its premises into a vernacular explanation. This trap of ordinary understanding though common speech is precisely what Heidegger is trying to avoid by reflecting further upon thought, speech, and action as the most crucial aspects guiding freedom in the realm of human existence. 


\subsection{Freedom of Thought, Speech, and Action}

In his search for the essence of freedom, Heidegger reflects on the implications of human thought, language, and action, to identify the origins and most basic elements of freedom. During his investigation into thinking Heidegger reaches the conclusion that: "Most thought-provoking in our thought-provoking time is that we are still not thinking." (Heidegger, "Basic Writings" 371) The key to this perplexing statement lies in Heidegger's belief that thinking is not an arbitrary flux of common images and ideas. We do not possess thoughts, Heidegger insists, and the more forceful we become in our thinking and the more we attempt to master thoughts, the smaller our chance to think freely, he explains. Heidegger's beliefs stem from a claim that "freedom in thought does not pertain to the mastery of ideas nor to the possessions of opinions or beliefs," observes Thiele, neither is it "found in the power and productivity of logic, science, or common sense." Rather it is diametrically different and contrary to calculative reason, adds Thiele, "because forgoing conceptual control in order to let Being be evidences freedom, thinking preserves the essential dignity of human being." (Thiele 108-109) Since the highest dignity of human being is fulfilling the role of Dasein, thinking requires a context in which it can be communicated allowing the disclosure of Being. 
For Heidegger, thinking is inextricably linked to language. Heidegger quotes Hölderlin and reflects on the hymn Mnemosyne, in which the poet attempts to capture in words the fragile nature of the human condition:

We are a sign that is not read,

We feel no pain, we almost have

Lost our tongue in foreign lands.

(Heidegger, "Basic Writings" 382)

Without memory, language is impossible. But what is the source of language? Heidegger's penchant for the poetic brings him to reflect on the mystery of language through a close etymological analysis of Greek and Latin. He concludes that "language is tongue, and it works by word of mouth." (Heidegger, "Basic Writings" 400) What resembles a simple statement reveals the close link between language and the most immediate manifestation of human existence in the world-the body. However, Heidegger insists language extends beyond our bodies and represents the most vital aspect of human existence that determines our dignity and destiny. "Human dignity consists in the full exercise of human freedom, and a crucial element of this freedom is manifest in speech that discloses what is," thus with this freedom, through language, humanity bares witness to Being (Thiele 131) and achieves its destiny as Dasein.

The relationship between language and thought is established and enforced through constant interaction between them. Memory is indispensable as it provides context for both thought and language. "Only 
when man speaks, does he think-not the other way around," (Heidegger, "Basic Writings" 381) notes Heidegger. Thought deprived of language remains un-communicated and thus completely concealed, while language without thought is incomprehensible. The language-thought link predicates the relation between language and action. "What we do largely depends on who we think we are, and who we think we are largely depends upon the language by which we define or describe ourselves to others." (Thiele 118) Heidegger is not interested in simply being "thought-provoking" (Heidegger, "Basic Writings" 391), nor is he attempting to steer us toward a definitive explanation of thinking. His mission is to question further and continue questioning until understanding begins to emerge. Turning toward another popular conception of freedom, Heidegger examines the implication of freedom as a form of mastery.

\subsection{Mastering Freedom}

I am the master of my faith:

I am the captain of my soul (Henley)

One of the most prevalent ways to understand freedom is through a practice of mastery. As an extension of negative freedom, mastery entices with a promise of influence over things and other people. The power of mastery is not only a declaration of sovereignty from others, but also an 
exercise of will to influence others by force. Mastery, in the social realm, has manifested itself historically in the practices of slavery, feudalism, and capitalism. In the realm of nature, it is manifested through the imposition of applied science exploiting the earth for its resources, often without consideration of is impact.

There are several problems with equating freedom with mastery. One of the biggest being the fact that "like Nietzsche's identification of freedom with radical individuality, the identification of freedom with mastery is pathological," observes Thiele. "When postmodern libertarians, like their positive and negative counterparts, completely equate freedom with mastery, they are effectively striking out against an ambiguous and overpowering world," he adds, "but the unrestricted identification of human freedom with the pursuit of mastery is pathological." (Thiele 71) The most evidently damaging aspect of mastery is its reliance on the subjugation of other people and nature. Freedom manifesting itself as mastery consequently results in slavery and suffering. It cannot be considered as freedom for it represents yet another form of dependency.

The masters imposing their will upon others (or on things) inevitably become dependent on the people (or things) they command. Freedom though mastery forced upon a society will eventually lead to authoritarian rule, where "given a choice between liberty or collective death, the pursuit of the former is unlikely to be sufficiently checked by fear of the latter," 
claims Thiele, adding that "freedom in a commons does bring ruin to all, but only if freedom is understood to entail the possession and mastery of things, the ability to act arbitrarily or wantonly in the world. By Heidegger's reckoning, however, freedom is something quite different." (Thiele 190) Freedom and mastery are thus completely incompatible, cancelling each other out. A society rooted in the master-slave dichotomy consists only of slaves and potential slaves, who live in perpetual struggle against one another and are in permanent fear of either becoming slaves or never escaping the misery of their oppression.

For Heidegger, freedom as mastery is not possible. He asserts that freedom is not the measure of the extent to which humans can subjugate nature and one another. Freedom directly concerns the possibility of human interaction with Being, not, as it is frequently assumed, human autonomy. Thiele elaborates on this notion in the following passage:

Traditional Western thinking posits freedom as the autonomous subject's most valued asset, as its capacity to comprehend and control what it confronts. Heidegger understands freedom as that which exposes human being to the incomprehensible and intractable: to Being. What is beyond one's power to master and possess, conceptually or otherwise, is beyond one's power to assess. Freedom, therefore, allows a reaching beyond calculation and valuation, beyond human jurisdiction. (Thiele 78)

Thus freedom must be something else than mastery, something reaching further than the ordinary concerns of humanity. Heidegger suggests that 
true freedom demands far less of human effort than mastery yet requires a lot more imagination.

Claiming that freedom is a process manifested in human thought, speech, and action, Heidegger offers an analogy of freedom as a journey leading through shadowy illusions on a path toward a clearing, a disclosure of truth. Rather than a constant attempt to control nature and time, freedom, as proposed by Heidegger, is simply letting ourselves and our world be, and acknowledging the rule of Being by taking our rightful place as the essential participants in the revelation of truth. The potential of humanity to achieve freedom lies not in our increasing ability to master nature, but through understanding that we are only an element in the process of freedom and that, despite our common perceptions, "freedom is not a thing or a property of man, but man is the possibility of freedom." (Heidegger, "The Essence of Human Freedom" 93). Unlike Kant's causality, Heidegger does not see freedom as a consequence of external pressures, but as a part of the essence of humanity, which is our role as the revealers of Being. To become truly free we must release ourselves to the possibility of Being.

\subsection{Freedom as Letting-be}

True freedom is openness, claims Heidegger. Only into a clear space will Being enter to reveal to us the truth. This means humans must 
allow themselves to become open and receptive to Being; they must let go of the will to mastery and let themselves follow their destiny. "Freedom was first determined as freedom for what is open up in an open region," claims Heidegger, and it "lets beings be the beings they are. Freedom now reveals itself as letting being be." (Heidegger, "Basic Writings" 125) Letting-be is an essential condition for establishing a relationship between human beings and Being. It is also a crucial aspect of the disclosure of truth. The connection between truth and freedom is built through the process of disclosure and formulates human existence, as Heidegger explains in the following passage:

Freedom, understood as letting being be, is the fulfillment and consummation of the essence of truth in the sense of the disclosure of beings. 'Truth' is not a feature of correct propositions that are asserted of an 'object' by a human 'subject' and then 'are valid' somewhere, in what sphere we know not; rather, truth is disclosure of beings through which an openness essentially unfolds. All human comportment and bearing are exposed in its open region. Therefore man is the manner of ek-sistence. (Heidegger, "Basic Writings" 127)

Human existence gains meaning only through Being, not through any form of struggle or self-determination. This remains one of the greatest challenges and mysteries of human life, precisely because human freedom is not determined by human ability and requires no specific effort on our part, other than openness to the disclosure of Being and letting-be. 
Heidegger radically shifts the perception of human freedom. His understanding of freedom extends beyond the negative, positive, or causal explanation of the phenomena. Disclosive freedom manifested as lettingbe, "is what allows a commons to be perceived as a commons in the first place - that is, a place defined not by ownership or dominion, but by guardianship," observes Thiele. "Disclosive freedom is precisely that which preserves the common world from ruin by preserving the meaning of a common world." (Thiele 190) It also offers a new potential for political appreciation of freedom that may develop on our planet one day. However, if freedom is not a human property, rather humanity is the property of freedom, is the actualization of human freedom even possible? Heidegger does not offer a definitive answer. He claims that "the possibility as also the actuality of freedom as freedom remains undefined, likewise (although this alone is constantly under discussion) the relation between the actuality of freedom and its possibility." (Heidegger, "The Essence of Human Freedom" 204) Human beings exist only as medium of Being and are free only when they fulfill their purpose of communicating Being to the world. Whatever interferes with that purpose ultimately reduces the voice of humanity to dissonance that over time dilutes our essence within an ocean of causality and sets us adrift in the uncharted territories of invisible dragons. 
The next section of this thesis will examine the connection between technology and human freedom and, specifically, Heidegger's belief that the greatest threat facing human freedom is technology. 


\section{LIBERTY IN TECHNOLOGICAL PERIL}

Technology provides us with numerous comforts and advantages.

Without it, our lives would probably be shorter and spent on struggles with the elements of nature, fear of darkness, wild beasts, and each other. The marvels of technological genius that once evoked amazement have become so entrenched in our daily routine that we cannot imagine our lives without them. Today, life without technology seems unimaginable for most of us. For some-such as patients relying on respirators or dialysis machines-it would frankly be impossible.

Technology has been etched deeply into the most mundane aspects of our existence. It has become not only ubiquitous but also invisible.

Offering a palate of impressive options, technology has become cheap and accessible. It empowers us with an abundant choice and previously-inconceivable possibilities. The minor drawbacks of technological advancement seem to pale in the face of its overall benefits. While technology can be used to inflict harm, it cannot be deemed as either inherently good or evil. Collectively we remain convinced that technology is neutral and, as long as we remain in control, it can only benefit humanity.

Nothing is farther from the truth. Heidegger shakes our complacency by arguing that modern technology is anything but neutral: that if we 
continue to pose as its masters, a horrible end awaits us. Modern technology is the greatest threat humanity has ever faced and "we shall never experience our relationship to the essence of technology as long as we merely conceive and push forward the technological, put up with it, or evade it," cautions Heidegger. "But we are [also] delivered over to it in the worst possible way when we regard it as something neutral; for this conception of it, to which today we particularly like to do homage, makes us utterly blind to the essence of technology. (Heidegger, "The Question Concerning Technology" 4) By narrowing the horizons of our thinking, the essence of technology threatens to deprive us of our freedom and to transform us into disposable resources at its command. Neither denial nor embracement of modern technology can avert this fate, as both are manifestations of our dependence and can only perpetuate the pathological enmeshment of humans and technology.

This section will examine the greatest danger that Heidegger claims the essence of technology poses to humanity-the distortion of our destiny as disclosers of truth—because of our delusory belief that we are the masters of technology. The focus of this section will turn to the threat humanity faces under the framework of technological essence that Heidegger sees as progressing toward enslavement of our species, and which, he insists, cannot be offset by straightforward human opposition or compliance. The conclusion of this section will examine the approach 
proposed by Heidegger to save humanity from technological peril by directing our attention toward renegotiating our relationship with technology, and returning to our role as revealers of Being unhindered by technological diversions.

\subsection{Endangering Freedom}

Modern technology endangers humanity with a plethora of threats. Technological inventions may inflict slow degradation or unleash irreversible devastation on the planet. For Heidegger, these threats pale against the elusive danger which "threatens man with the possibility that it could be denied to him to enter into a more original revealing and hence to experience the call of a more primal truth." (Heidegger, "The Question Concerning Technology" 28) Nonetheless, it is difficult to imagine anything more frightening than a semi-autonomous malfunctioning machine triggering a global nuclear war or releasing bio-chemical agent that destroys humanity. These scenarios are realistic enough to evoke genuine fear-fear sufficiently vicious to ignite global political paranoia. Precautions are taken to ensure only a human hand can execute a launch of nuclear weapons. Yet, according to Heidegger, the real danger lurks beneath the easily identifiable—not within technology per se, but in its murky essence-deep within the cipher that guides the human hand. 
Heidegger interprets the essence of technology as Enframing (Gestell) that challenges human beings "to reveal the real, in the mode of ordering, as standing-reserve" which holds sway over the disclosive destiny of humans. He claims that "the revealing that holds sway throughout modern technology does not unfold into a bringing-forth in the sense of poeisis," rather it "is a challenging [Herausfordern], which puts to nature the unreasonable demand that it supply energy that can be extracted and stored as such." (Heidegger, "The Question Concerning Technology" 14) The conclusion here is that the direct imposition of modern technological essence endangers disclosive looking and eventually leads to loss of freedom. How is it possible that a particular outlook is capable of depriving humanity of its liberty? The explanation hinges upon Heideggerian understanding of the essence of human freedom, which is the dignity to be Dasein and aid revelation of Being.

Humanity relies on poeisis to partake in the process of revealing Being. Heidegger claims that "Enframing conceals that revealing" and "not only conceals a former way of revealing, bringing-forth, but it conceals revealing itself and with it that wherein unconcealment, i.e., truth, comes to pass." (Heidegger, "The Question Concerning Technology" 27) Poised outside the reach of truth, human beings are deprived of their experience of freedom as Dasein and diminished to a preoccupation with self-absorbed existence. As creatures endowed with language and destined to 
communicate with Being we are impoverished "when we are immersed in seeing the world as enframed," claims Pattison, because "we fail to see or to understand what it is for Being truly to be." (Pattison 15) We are then denied the possibility of establishing a free relationship with our world, when "by occluding the objectness of being, [Enframing] takes away [our] ability to stand in a care-ful, non-violent relation to them," explains Young, and by "occluding poeisis, the thingness of beings, it takes away the will to stand in such relationship." (Young 53) This violation of the essence of human being and the growing violence of technological solutions leads to degradation of human dignity and prevents us from achieving our destiny which, according to Heidegger, is greater than our dreams of technological utopias.

Enframing poses the greatest danger by concealing the essence of humans "for if humans do not see their essence, if they are mistaken about their freedom, then neither will they see how to fulfill their essence and how to exercise their freedom," (Rojcewicz 146) argues Rojcewicz. According to Heidegger's belief, Enframing quietly yet persistently delivers our demise because "humans will not even see how modern technology threatens their freedom. Their oblivion will place humans in danger of relinquishing their freedom and becoming blind slaves." (Rojcewicz 146) It is the greatest danger because it is an actual current threat, already taking place in our world, and not a potential danger of a possible future mishap. Enframing is systematically suffocating liberty. 
Realization of the powerful sway of Enframing leads to a reaction in humans to bend technology to human will. It is almost an instinctive reaction to try to dominate what is overpowering us. The mission of modern science can be seen as a race to keep ahead of technology; to constantly invent new gadgets and new methods as a way of bringing order to the expanding sway of technological essence. According to Heidegger, however, this approach is itself technological and can only lead to a strengthening of the power of Enframing to manipulate humanity. Despite our lofty ambitions and ingenuity, human attempts to master technology have resulted only in the perpetuation of the grand technological delusion.

\subsection{Masters of Delusions}

Nothing has been as liberating for humankind as the mastery of fire. Nothing has angered the gods more than the Promethean trick that illuminated the darkness of the human world with the power previously reserved for divine purposes only. Nothing has ever equaled the cruelty of the punishment sent upon Prometheus and humanity. While the thief of sacred flame suffers eternal agony of horrendous death, humans have fallen under the enchantment of the shadows cast by the fire they have been given. In Plato's cave, humanity succumbed to hubris and comfort by substituting reality for mere illusion of a shadowy dance projected on the 
wall. What have we done with divine light? Why have we taken it deep into a dark cave instead of using it to illuminate the shadows of the world beneath the gaze of gods? Perhaps it was the shame of our deceit, perhaps, as Heidegger seems to suggests, it was not entirely our choice.

Armed with the light stolen from Olympian summit, we began to think of ourselves as masters-masters of the fire, the darkness, and the world. Fashioning reality to suit our caprices has filled us with the belief that humans are the creators of everything around us, thus falling into the trap of Enframing. Heidegger expounds on this in the following passage:

man ... exalts himself to the posture of lord of the earth. In this way the impression comes to prevail that everything man encounters exists only insofar as it is his construct. This illusion gives rise in turn to one final delusion: It seems as though man everywhere and always encounters only himself. ... In truth, however, precisely nowhere does man today any longer encounter himself, i.e., his essence. Man stands so decisively in attendance on the challengingforth of Enframing that he does not apprehend Enframing as a claim, that he fails to see himself as a the one spoken to, and hence also fails in every way to hear in what respect he ek-sists, from out of his essence, in the realm of an exhortation or address, and thus can never encounter only himself. (Heidegger, "The Question Concerning Technology" 27)

Enframing entices domination of things and perpetuates the delusion that forcing earth, water, air, and fire to yield their powers ever more efficiently, 
with the use of ever more effective technological tools, constitutes a greater control over nature.

Through Enframing we embrace power and control as manifestations of freedom. We reduce technology to a set of tools to help us control the world and reshape our reality. We perceive technology as an instrumental phenomenon. We are inclined to perfect our tools of control and "so long as we represent technology as an instrument, we remain held fast in the will to master it. We press on past the essence of technology." (Heidegger, "The Question Concerning Technology" 32) Here Heidegger suggests that our ability to attain truth and to witness reality has been warped by the bluntness of the tools in which we place our trust. Our imperfect technological paraphernalia can probe for truth only within a very shallow range of experiences, leaving us guessing about the full depth of reality. "The limitlessness of our technological penetration ... is only an 'illusion' that, in turn, gives rise to the 'delusion' of our omnipresence," observes Thiele, "ultimate victory of technological humankind is indeed delusory," he adds, and eventually "delusion may become accepted as reality." (Thiele 203) It could be argued that modernity is an acceptance of numerous delusions that have been incorporated into the common consciousness of human experience.

Through our relentless pursuit of ultimate mastery over things, we become slaves to them. The essence of technology defines the spirit of 
modern times and defines our relationship with the world and Being. "The truth about mature modernity (that which we misleadingly call 'postmodernity') is that, like the broom of Goethe's sorcerer's apprentice or 2001's HAL, the machine that was supposed to be our slave has become instead our master." (Young 46) This realization evokes shock and prompts for immediate action to prevent this condition from deteriorating. How can we allow ourselves be ruled by our own creations? Can we call ourselves masters if we cannot successfully exorcise the ghost from the machine and regain control? These questions imply a need for even greater control, even greater mastery of our technological tools. In the opening chapter of On the Social Contract, Jean-Jacques Rousseau declared: "One who believes himself the master of others is nonetheless a greater slave than they." (Rousseau 46) Heidegger would say, we could not have strayed further from the path of truth than in our futile attempt to master technology.

Herein lies the locus of our illusion. We are "victimized by the delusory experience of absolute freedom, complete mastery, the ability to impose [our] will everywhere. For Heidegger, this attitude is a delusion, because in attempting to be master, humans are actually altogether 'in attendance on the challenging of com-posing," argues Rojcewicz. It is pointless to impose our will upon technology, because "to pursue technology headlong is actually to surrender one's freedom to the allencompassing imposition," explains Rojcewicz. "It is to be a slave to the 
all-encompassing imposition." (Rojcewicz 145) But the struggle to master technological tools, which are obviously no longer under our control, is not only a worthless investment of our effort but also an invitation to even greater disaster. The pursuit of liberation through technology may lead to greater enslavement if we fall victims to our own rules and descend to the ranks of disposable resources ordered by Enframing.

\subsection{Disposable Humans}

It is the vanity of human beings to become immortal. The promise of eternal life has attracted many devout followers, regardless of religion. Yet the promise of life after death or reincarnation sustains the conformity only until technology reveals another possibility: endless life in flesh. Why settle for an unverifiable guarantee if you can choose to believe in what you can perceive most immediately? The intention behind reanimation of Frankenstein was a desire to conquer life by challenging death. Flesh has become a new promising resource.

Surprisingly, the appeal of eternal life, in flesh or not, has never been diminished by the lack of comprehension of eternity itself. The mystery of both death and eternity looms beyond human grasp, yet it seems we are no longer troubled by what we do not know nor understand. We have lost our interest in questioning hidden truths, what Heidegger suggests is the sign of 
our demise. "As soon as what is unconcealed no longer concerns man even as object, but does so, rather, exclusively as standing-reserve," notes Heidegger, "and man in the midst of objectlessness is nothing but the orderer of the standing-reserve, then he comes to the very brink of a precipitous fall; that is, he comes to the point where he himself will have to be taken as standing-reserve." (Heidegger, "The Question Concerning Technology" 27) The direct implication of humanity reduced to standingreserve would result in a complete loss of freedom. Slavery under the sway of the essence of technology could be the worst fate humanity could ever construct for itself. While this may seem nearly inevitable, it is not our destiny at all. Our destiny remains undetermined. Enframing is leading us to believe otherwise.

We often say that science is a process of determining the nature of reality. The essence of technology holds us in the illusion that we can simplify everything: speak in plain language, decipher our DNA, or inflict greater damage with a smaller explosive. Heidegger sees this as the fastest path away from freedom and leading eventually to slavery, as Rojcewicz explains in the following passage:

Humans will be tempted to apply their science to themselves and thereby reduce themselves to the formulas they apply to things. Like determined things, humans will become the outcome of the exterior forces. ... Consequently, humans will view themselves not as 
masters but as slaves, not free but determined, mere cogs in the great machine of forces around them. (Rojcewicz 145)

It could be argued that the process of reductionism is well underway. Not a day passes without hearing of a contraption that has been made smaller or of a technological process that has been made faster, more efficient, cheaper, and more accessible for everyone (or at least those with the means to afford it).

In factories and offices, employees suddenly have become human resources managed, streamlined into more efficient systems of production, and motivated to maximize their output while minimizing their requirements through technological substitution of needs. While it is difficult to deny that "no more horrific and ruthless example of the total ordering of humanity as standing-reserve has ever been constructed than that of the Nazi concentration camps," Thiele argues our "present-day genetic research, which bears out Heidegger's prediction of the artificial breeding of human material, is ultimately no less dangerous for all its humanistic appeal." (Thiele 198) Hidden from public scrutiny, under the sway of the technological will to power, scientists and technocrats may be scheming to construct Franken-armies_cheap and disposable, better than humans. Perfectly commendable drones would never demand higher pay, better treatment, longer rest hours, or even fathom demanding human rights. The power of Enframing, regardless of whether we chose to resist or abet it, will 
bind us to further reliance on technology and lead us into deeper dependency on it. Resistance is futile; humanity eventually will be assimilated into the realm of disposable resources. Is there any motivation to struggle?

\subsection{Passionate Technophobes and Technophiles}

Man was/is born free, and everywhere he is in chains (Rousseau 46)

Ongoing struggle characterizes the nature of humanity. What constitutes the nature of our struggle? When Heidegger gazed through his technological lens at Russeau's verse he concluded: "Everywhere we remain unfree and chained to technology, whether we passionately affirm or deny it." (Heidegger, "The Question Concerning Technology" 4) He suggests that our strong and barely controllable emotions to either dismiss or obey the essence of technology will only thrust humankind deeper under the control of Enframing. By blindly embracing technology, we are positioning ourselves under its sway, but we "are by life's necessities dependent upon technology and labor," points out Rickey. "Until manna falls from heaven and the elements withhold their violence from our bodies," he adds, "nature demands that we cultivate and build. Heidegger thus considered a blanket condemnation of technology ridiculous." (Rickey 155) 
Only when we fully reflect on technology by questioning it deeply, only "when we consider the essence of technology, then we experience Enframing as a destining of revealing," explains Heidegger. "In this way we are already sojourning within the open space of destining that in no way confines us to a stultified compulsion to push on blindly with technology or, what comes to the same thing, to rebel helplessly against it and cure it as the work of the devil." (Heidegger, "The Question Concerning Technology" 25-26) As Heidegger suggests a middle way for us to approach technology, he almost implies a personal regret in taking sides during the passionate ascent of Hitler. His own bitter experience stands as a warning against any popular euphoria that is capable of shamelessly pushing even the brightest among us into dark corners of history.

Following a technological path or rebelling against technology manifests a dysfunctional dependence on technology. Rojcewicz illuminates Heidegger's perplexing logic regarding this issue in the following passage:

If we are passionate about technology, then technology itself will dictate the terms of our engagement with it-hence the enslavement. Whether we are passionately pro- or passionately anti-technology, we will be too tightly bound to it to take up an autonomous, freely chosen stance. We will constantly take direction from technology; which is to say that technology will constantly dictate to us or impose on us, whether we pursue it or oppose it. (Rojcewicz 151) 
Heidegger believes the struggle against or through technology is fruitless. Instead, he advocates taking a new approach to shaking off the yoke of technology. What is the path that Heidegger suggests we take? Other than indecisive anticipation, what lies between denial and support of technology? Has our struggle for freedom become a struggle for liberty from technology?

\subsection{Freedom from Technology}

Reflecting upon the seemingly position of humanity in relation to technology it appears that we are doomed to continue falling and permanently remain under the sway of Enframing. This is not what Heidegger envisioned for us. Despite his gloomy outlook on the chance of humanity attaining freedom, our future is not determined. If we remember Heidegger's claim that we are Dasein—the revealers of truth—we still can choose to fulfill our destiny in that role. But we can also decline to court Being.

One of the elementary goals of Heidegger's reflection on technology is to discover a path toward a free relationship between humanity and technology. (Pattison 71) Neither resistance nor obedience to the call of technological essence will free us from its sway. "Quite to the contrary," Heidegger claims, "when we once open ourselves expressly to the essence of technology, we find ourselves unexpectedly taken into a freeing claim. 
(Heidegger, "The Question Concerning Technology" 25-26) However, he does not offer any explicit remedies for our technological afflictions. We can only arrive at a route for ourselves through reflection on technology and a constant questioning of its essence.

In what way can humanity achieve freedom in relation to technology? Enlightened by Heidegger's reflection, Pattison suggests first steps on the path to freedom in the following passage from The Later Heidegger.

Firstly: that we do not allow ourselves to be mesmerized by technology itself and its 'success', but rather keep our sight on the essence of technology.

Secondly: we confront the essence of technology in the light of what is truly essential to humanity-to return to our human essence, specifically thinking and language. The key to the question of technology, ... is to think upon Being. (Pattison 71)

The concept of freedom in Heidegger's thought between 1950s and 1960s is not fatalistic. He suggests that a proper response to the issue of technology and the possibility of another beginning in the history of Being can arise from within individual human freedom if we embrace our role as Dasein.

However, Heidegger insists the revelation of Being requires our openness to receive, as Thiele explains in the following passage:

Openness to beings, of which techné constitutes one particular mode, thus describes human being's assumption of a solicitous relationship to the world. This solicitation, Heidegger indicates is the 
burden of freedom. Ironically, human freedom (at least in the Western world) has typically been identified not with the solicitation of what lies in potential, but with the power to master and possess what is actual. Modern technology receives its defining characteristics therefrom. (Thiele 195)

A proper relation to technology requires more than the binary yes-no attitude we have cultivated up to now. To find freedom, we need to be more objective in our view of technology. "Freedom, for Heidegger, will involve distancing ourselves from technology, detaching ourselves from it, not by opposing it (which is not detachment)," explains Rojcewicz "but precisely by extricating ourselves from a passionate, uncompromising, antithetical attitude toward it" or specifically he adds "if we are to be free, we will need to find (or, rather, we will need to be given or be shown the way to) a nontechnological or nonimpositional attitude toward the very attitude of imposition." (Rojcewicz 151) It will require us to reach out for the powers invested in us by Being, which lie beyond the span of our technological leash. To move beyond our limitations, it is crucial to submerge deeper into Heidegger's investigation into the essence of technology. Will technology resort to nihilism in order to liberate us from our delusions about what its essence truly is? 
The last part this thesis will examine more closely Heidegger's opinion on the prospect of humanity attaining freedom through—and despite-technology by positioning itself in a proper relation to the essence of technology. Heidegger envisions an arrangement where human beings neither surrender in blind obedience to the call of technological thinking nor automatically reject technology without first exploring its possible benefits. 


\section{FREEING ESSENCE OF TECHNOLOGY}

Under the shadows of history and the depths of despair, one hope has sustained humankind_freedom. While some may feel we are on a

downward spiral toward technological ruin, humanity is not destined to sign off without a bang or a whimper. We are a resilient species, capable of not only rearranging the world to our advantage but also skilled in reinventing ourselves and adapting to the world around us. Perhaps the latter skill is nowadays only a trace of our former talent, but it is precisely what Heidegger attempts to summon back into our modern consciousness with his poetic language.

Heidegger encourages us to "open ourselves expressly to the essence of technology" where we will "find ourselves unexpectedly taken into a freeing claim." (Heidegger, "The Question Concerning Technology" 25-26) However, since he offers little in terms of direction on how we may achieve this, it is difficult to chart a proper course. The few signs he offers are left for our own interpretation. Deciphering Heidegger's thoughts on this is a formidable challenge, as his work is far from a methodological recipe composed to yield predictable results and presents many chances for misinterpretation. The difficulty and impenetrability of Heidegger's language has been a target of his numerous critics. However, another possibility exists: Heidegger, in the spirit of Nietzsche, may have 
been writing for a small select audience of adventurous thinkers. Left at the mercy of their wits, courage, and determination, only the most persistent readers of Heidegger tackle his approach to the understanding of human freedom. Much depends on the questions they choose to pursue.

How can we develop a proper relationship toward technology? How can we avert or mitigate the harmful influence of Enframing? "Despite the ills caused by modern technology, Heidegger's path to overcoming nihilism leads through technology," claims Rickey and "only by coming to an adequate relationship with the essence of technology can human beings relate themselves to $[B]$ eing as freedom." (Rickey 155) However, a proper relationship cannot be achieved completely on our own, it requires the willingness of Being to bring the truth to us, thus we have much to do in order to prepare ourselves for the reception of this truth. (Rojcewicz 221) Faced with this predicament we "must await-i.e., actively prepare for-a wholehearted approach to mankind on the part of Being," argues Rojcewicz. "If the self-disclosure of Being is ample enough, and if humans have prepared a place for this self-disclosure with sufficiently unrelenting courage, then the partnership between Being and mankind may yield the truth." (Rojcewicz 221) While waiting for Being to bestow us with its gift of truth may sound simple, the practice of conscious receptiveness, as any practitioner of Zen meditation will attest, is demanding. It requires immense concentration to embrace stillness. 
This section of the thesis will synthesize Heidegger's outlook on the possibility of humanity obtaining freedom through technology by positioning itself in a proper relation to its essence. By analyzing the potential of deliberate contemplation and detachment, this section will consider the approaches, which according to Heidegger, would allow us to live with technology yet not fall under the enthrallment of technological things and the sway of Enframing. This section will also examine Heidegger's suggestions for reattachment of humanity to Being through cultivation of openness to mystery and art, as well as questioning that invites revelation of truth from Being.

\subsection{Deliberate Contemplation}

When we learn to think at an early age, we first learn how to analyze our environment-to calculate imminent threats and opportunities. Calculation is the mode of thinking that dominates most of our intellectual efforts on a daily basis. Beyond calculative, or practical thought, lies the realm of philosophy and imagination. These are encouraged at a young age, but eventually diminish or are discouraged outright in adulthood. Eradication of engagement in non-productive thinking eventually results in shrewdness and efficiency—maximum results engaging minimum effortthe credo of modernity. 
Continually shaped by outside forces, we succumb to beliefs that require the least effort to hold, thus we grow to be very useful and pliable. Our thinking is influenced by the shifting moods of time, yet "whatever external actions are performed, whatever social policies might be adopted by, for example, the state, they can never, in Heidegger's sense, make one free," observes Young. "The state may order the world in whatever way it likes - it might, as the Heidegger of 1934, crazed by the intoxication of Nazi power proposed, try to create a new clearing of being by destroying industrial civilization and replacing it with a pre-industrial form of life," Young reminds us, "but without the inner turn of the heart that 'clears' the clearing, all such action will be futile." (Young 87) For Heidegger genuine thinking is not a calculative effort aiming to produce an authoritative objective conclusion. He insists there is a higher purpose for our intellectual powers.

Thinking is the conversation of humanity with Being, claims Heidegger, and "so long as we do not, through thinking, experience what is, we can never belong to what will be." (Heidegger, "The Question Concerning Technology" 49) Experiencing Being (is-ness, or what is) does not involve an exercise of logic or reason, but rather a meditative contemplation-a quiet considering of the truth reaching beyond the essence of technology and enchantment of technological tools. As Heidegger suggests, "contemplation may allow us to see through the meretricious attraction of technological things," infers Rojcewicz. "[Heidegger's] point is that contemplation allows us to put technology into 
perspective, to relativize technological things, by opening up an even higher realm, the one of Being," he adds. (Rojcewicz 219) Contemplative thinking offers the possibility of liberating humanity from the damaging effects of Enframing, of leading us to greatness through a renewed attachment to Being while diminishing our dependency on technology.

Heidegger offers contemplation as an antidote to the perspective limitations of technological thinking. "Contemplation (theoria)," explains Arendt in Human Condition, is "a human faculty, distinctly different from thought and reasoning, which occurred in the Socratic school and from then on has ruled metaphysical and political thought." (Arendt 16) Engaging in contemplative thinking allows us to cut through the web of Enframing and escape toward "the attitude of detachment," argues Rojcewicz, which is the prerequisite to "what Heidegger calls 'openness to the mystery' and 'autochthony."' (Rojcewicz 218) Although it entails calm and reflective meditation, contemplation is not a passive state. The detachment it generates does not translate into aloofness or indifference. Contemplation leading to detachment is the first step in the path to a freer relationship with technology. 


\subsection{In This World, but Not of This World}

In order to reconnect with Being, we must become detached from the essence of technology. As the path to salvation leads through technology, we must retain this detachment while finding our way. According to Heidegger, humanity must exert all its efforts and focus its essence. To attune human essence to the essence of technology and to establish "an essential relationship between technology and man in respect to their essence, modern man must first and above all find his way back into the full breadth of the space proper to his essence," argues Heidegger. This space can be found by detachment not only from technology, but also from ourselves, in order to find the "dimension that unites [man's essential being] to something beyond itself solely from out of the conjoining relation that is the way in which safekeeping of Being itself is given to belong to the essence of man as the one who is needed and used by Being." (Heidegger, "The Question Concerning Technology" 39) Detachment can return to us the dignity of our destiny as Dasein. We must come to realize that technology is not our foe, but it is not necessarily a friend either.

Heidegger is not against using technological things but believes in using them with caution, Rojcewicz argues. It is possible to benefit from the advantages offered by technology and not fall under the sway of the essence of technology as long as we "deny them an exclusive claim." 
(Rojcewicz 219) Expending Heidegger's thoughts on this matter, Rojcewicz explains in the following passage:

We can use technological objects, and even use them just as they were devised to be used, and yet we can thereby remain free of them. We can let the technological objects take their course as things that do not concern us in what is most central and proper to us. We can say 'yes' to the ineluctable use of technological objects and can at the same time say 'no' to them, insofar as we refuse to allow them to claim us exclusively and thereby warp, muddle, and, ultimately, lay waste our essence. (Rojcewicz 219-220)

The argument stems from Heidegger's earlier claims in The Question Concerning Technology suggesting a new relationship with technology. Yet, while detachment appeals as a viable solution to the issue of technology, it remains questionable whether we are in fact capable of distancing ourselves from technology that is expanding its network and becoming thoroughly enmeshed with our existence. The realities of the modern world leave us little time for reflection and contemplation and, so, the practice of detachment becomes difficult, if not impossible.

However, if we do find the time and make the effort, meditative thinking offers some potential. By entering a state of contemplative thinking we can "withdraw ourselves from the 'enframed' life of mainstream modernity, engage in a kind of 'emigration' that takes us away from the violent and dis-enchanted centre of our culture and relocates us at its margins," argues Young. Thus withdrawn, "we become, ... , in Nietzsche's 
sense, 'untimely' - the condition in which, according to Heidegger, 'essential' thinking has always found itself." (Young 89) This way, we remain in this world but are no longer constrained by its limitations, particularly those imposed by the essence of technology. Unbound, we regain our freedom and can open ourselves to the mystery of Being.

\subsection{Cultivating Openness to Mystery}

As long as you still experience the stars as something 'above you' you lack the eye of knowledge (Nietzsche, "Beyond Good and Evil" 80)

Contemplation and detachment can take us outside of ourselves. To prevent technology from standing over us cannot be achieved by subjugation. That would be on a par with trying to rise above the stars in the heavens. Heidegger tells us that the mystery of Being appears farthest away, because it is the closest. "When we look into the ambiguous essence of technology, we behold the constellation, the stellar course of the mystery," he states. "The question concerning technology is the question concerning the constellation in which revealing and concealing, in which the coming to presence of truth, comes to pass." (Heidegger, "The Question Concerning Technology" 33) The mystery remains inexplicable, holding a secret, a hidden truth which we are invited to discover. To move into the realm of mystery, rather than trying to force the mystery into our pragmatic sphere, we should raise our consciousness to its level. 
Heidegger recognizes the difficulty in convincing rational human beings that logical coherence, utilitarian efficiency, and the advancements in technological instruments are mere distractions on the path to truth. We are attached to our well-worn convictions and addicted to daily doses of technology. However, to open ourselves to the mystery of Being we must start by freeing our essence by denying technological distractions. Heidegger explains this in the following passage:

as we seek to give utterance to insight into that which is, we do not describe the situation of our time. It is the constellation of Being that is uttering itself to us. But we do not yet hear, we whose hearing and seeing are perishing through radio and film under the rule of technology. The constellation of Being is the denial of world, in the form of injurious neglect of the thing. Denial is not nothing; it is the highest mystery of Being within the rule of Enframing. (Heidegger, "The Question Concerning Technology" 48-49)

It is important to recognize that the power of denial of technology or Being is within the realm of human free will. While truth may be bestowed upon humans by Being, our denial or acceptance of this gift cannot be determined by outside forces; it must be invoked from within ourselves in acts of individual free choice. To accept Being, we must achieve the denial of technology in the course of our own efforts.

This denial can be achieved through detachment and contemplation directed at technical things-as the manifestations of the essence of technology. Heidegger feels proper "contemplation allows us to put 
technological things in their place, which amounts to detachment from them," according to Rojcewicz. "Putting them in their place must indeed be understood in the sense of demoting them, dismissing them from the highest place; i.e., it involves the recognition that they do have a legitimate place." (Rojcewicz 219) Quiet reflection allows meaning to emerge from the flux of ordinary life filled with chores assuring the continuity of our material existence. However, contemplation should not be equated with passivity and meekness which some religions hail as prerequisites to spiritual awakening. Heidegger insists '"Being is not God.' Unmistakably, however, it's sufficiency unto itself, its ubiquity 'nearest to' and 'furthest from' man, have a marked theological edge." (Steiner 64). His description of Being carries religious undertones. However, Heidegger's ontology is not a disguise of a new onto-theology. Reflecting upon Being does not lead to detachment from life on earth; it is not a consideration of the after-life.

Contemplation, although distinct, is related to action in philosophical accounts of ancient Greek thought. "The term vita activa, comprehending all human activities and defined from the viewpoint of the absolute quiet of contemplation," points out Arendt, "corresponds more closely to the Greek askholia (unquiet), with which Aristotle designated all activity; (...) vita activa receives its meaning from vita contemplativa." (Arendt 15-16) She also adds that "truth, be it the ancient truth of Being or the Christian truth of the living God, can reveal itself only in complete human stillness." (Arendt 15) Thus it is the stillness in contemplative effort that invites Being 
to reveal truth to us-the truth that provides meaning to our actions. Yet this effort does not imply we become mystics and seek truth beyond the limits of our comprehension; rather, Heidegger claims, we can approach the mystery by engaging in art and the piety of thought, which is questioning. (Heidegger, "The Question Concerning Technology" 35)

\subsection{Freeing Realm of Art}

Poetically dwells man upon this earth. (Heidegger, "The Question Concerning Technology" 34)

Technology and art share the etymological root in poeisis and represent aided bringing-forth. Today, their common origin has been all but forgotten. While technology is hailed as the revered zeitgeist propelling humanity to greatness, art has been relegated to the margins of human action as unproductive ersatz activity. Generally perceived as soley aesthetic fancy practiced by self-indulgent individuals bent on ascribing original importance to their misinterpretations of reality, artistic endeavor today is often appreciated only when vulgar, scandalous, or capable of generating substantial profits.

The contemporary separation of art and technology has resulted in a spiritual malaise. For the ancient Greeks, art did not have any appreciative value in terms of bringing a return, argues Rojcewicz, rather it represented the human aspiration to rise above individual subjectivity and elevate the 
human experience to the realm of Being. (Rojcewicz 187) "Heidegger often stresses that the modern distinction between the productive crafts and the fine arts was foreign to the Greeks, that for them, artists were as much 'technicians' as craftsmen," points out Young, adding that thinkers were in a similar position. "The Greeks, [Heidegger] says included the arts of the mind' as a species of the bringing forth of techné." (Young 40) Enframing technology has divorced art and technology what resulted in the retreating of Being and concealment of the path of disclosure under the veil of technological thinking.

Forgetting the connection between art and technology is possibly one of our major contemporary oversights. By limiting the role of art in our lives strictly " to provid[ing] 'aesthetic experiences,' ... according to Heidegger, we are also in the domain of Enframing," argues Pattison, "because we have already determined the realm of art in advance as the site of a specific kind or range of experiences, experiences that, as modern aesthetics understands it, have nothing to do with 'truth.'" (Pattison 56) As a result, this restricted interpretation of the role of art and our unquestioning devotion to technological perception of the world deprive us from experiencing the presence of Being. This represents a substantial impediment to Heidegger's proposal of establishing a free relationship between humanity and technology through art.

Returning to the path of art is how Heidegger suggests we can recapture the attention of Being. For art offers a dimension where humanity 
could transcend Enframing. Heidegger explains this in the following passage:

Because the essence of technology is nothing technological, essential reflection upon technology and decisive confrontation with it must happen in a realm that is, on the one hand, akin to the essence of technology and, on the other, fundamentally different from it. Such realm is art. But certainly only if reflection on art, for its part, does not shut its eyes to the constellation of truth after which we are questioning. (Heidegger, "The Question Concerning Technology" 35)

Art may save us by opening our experience to poeisis-the antidote to the sway of modern technology (Rojcewicz 206)-which determines our understanding of the world and ourselves, "and hence our being in that world," Young adds. "If we are to overcome the violence of the modern technological relationship to reality we must learn, once again," emphasizes Young, "how to inhabit the festive state, learn, in [Erich] Fromm's language, to inhabit the state 'being' rather than that of 'having.' In Hölderin's language, we must learn to become 'poets.'" (Young 62)

It is important to stress that Heidegger does not view art as a panacea to our modern technological malaise without a dose of skepticism. Acutely aware that art is only an attempt to reach out to Being, he warns against hubris and complacency in drawing definitive conclusions from his insight into the essence of technology. Despite our best efforts and honest intentions the nature of Being remains a mystery. "Whether this highest 
possibility of its essence may be bestowed on art in the midst of the extreme danger, no one can tell," (Heidegger, "The Question Concerning Technology" 35) he cautions in his conclusion of The Question Concerning Technology. Here, Heidegger suggests "it is a question of whether this possibility will be bestowed on art" claims Rojcewicz. "In other words, it is primarily in the hands of Being, in the hands of the inspiring gods," Rojcewicz adds. "That is why, ultimately only a god can save us. We humans shall have to wait." (Rojcewicz 207) This waiting is the hardest task of all; this waiting in a state of detached contemplation of mystery requires the practice of poetic art in the path of questioning, as "questioning is the piety of thought." (Heidegger, "The Question Concerning Technology" 35) Poetry opens us to this questioning, but what does Heidegger mean by questioning and what does he believe makes it pious?

\subsection{Piety of Astonishing Thought}

The font of genuine thought is astonishment ... at and before being. Its unfolding is that careful translation of astonishment into action which is questioning. (Steiner 56)

Ordinarily, a question implies an answer. The technical-empirical inquiry seeks to resolve a particular problem by posing a precise question anticipating a response and is expected to satisfy a demand for specific information. In contrast, Heidegger's inquiry is a perpetual process of eliciting clues along the path of truth and not an inquisition seeking to 
deliver a sentence ending the process of questioning indefinitely by resolving a problem. Additionally, against the grain of general belief, according to Heidegger, not all questions need to be asked. Heidegger believes that "questions ... are only worth asking of that which is worth questioning," claims Steiner, "of that 'which is questionable in a sense implying not the guarantee of an answer, but at least that of an informing response'" (Steiner 29) Here, Heidegger, akin to Nietzsche, reveals an elitist undertone. Who will decide which questions to ask? For Heidegger, the main concern is not how we should determine questions, but rather how we should approach thinking.

The form of inquiry he proposes requires an open dimension of thought, beyond the limited space provided by technological thinking. "Such realm is art," claims Heidegger. "But certainly only if reflection on art, for its part, does not shut its eyes to the constellation of truth after which we are questioning," he adds. (Heidegger, "The Question Concerning Technology" 35) As long as we do not expect poetic questioning to provide us with answers to practical problems, Heidegger encourages us to thoroughly question the essence of technology.

For Heidegger, art is a form of questioning that does not offer any answers at all, for him, art only raises further questions, Rojcewicz notes. Art poses questions and considers the mystery of Being; it puts us in a reflective and meditative state-a con-templation—which is precisely "what is carried out in a temple, namely a communing with the divine, a raising of 
the sight to the gods, a gazing into the realm of Being." (Rojcewicz 216) The pious approach to questioning suggested by Heidegger represents a rejection of an empirical approach to the mystery of Being as problem solving. Heidegger proposes a distinct form of inquiry, as Rojcewicz explains in the following passage:

questioning is for [Heidegger] a thinking that springs from an attitude of piety, i.e., from submissiveness to something recognized as ascendant over the questioner. The only genuine question, the only question to which we do not already know the answer, is the one posed to something ascendant. That which is ascendant over humanity is Being, the truth, the essence. (Rojcewicz 208)

The questions of Being and essence provide the basis for Heidegger's philosophic journey. They cultivate the roots of his thinking and his ontological approach to understanding of humanity. He believes that by harnessing the power of poetry and art we can navigate the treacherous currents of technological essence toward our reunification with Being. Questioning ensures we remain on the right course.

Inquiring about the essence of technology is critical for Heidegger, since it empowers our efforts to establish a free relationship with technology, as he emphasizes in the following passage:

the more questioningly we ponder the essence of technology, the more mysterious the essence of art becomes. The closer we come to the danger, the more brightly do the ways into the saving power begin to shine and the more questioning we become. (Heidegger, "The Question Concerning Technology" 35) 
Here, Heidegger suggests that "the more we question technology, i.e., the more we think about its dangerous essence, the more we are able to come into that which might save." (Rojcewicz 209) It is another question, whether humanity recognizes a need to be saved. Yet another whether we are capable of mustering the humility and courage to seek help outside the realm of ordinary being.

Heidegger's formidable argument in The Question Concerning Technology points in the direction of that fundamental question concerning humanity: what is the meaning of our being? "For Heidegger, to be is 'to speak being' or, to question it." (Steiner 52) Ultimately, it is about our will to understand ourselves in the process of trying to understand Heidegger. But "to 'understand' Heidegger is to accept entry into an alternative order or space of meaning and of being," cautions Steiner. "It is not 'understanding' that Heidegger's discourse solicits primarily. It is an 'experiencing,' an acceptance of felt strangeness." (Steiner 18) It is akin to asking questions that can only elicit more questions-standing astonished in the presence of Being. 


\section{CONCLUSION}

According to established beliefs, technology is neutral. On one hand, it liberates us from the hard labor necessary to sustain our bodies and survive on this planet. It also empowers us to manipulate the environment to suit our needs, protects us from the harsh natural elements, and liberates us to spend more time on leisure and entertainment. But on the other hand, technology carries the potential to destroy or enslave us if used for wicked ends. Seen as neither inherently good nor evil, technology resembles a palette of tools dependent on our intent behind their application. As long as we keep technological instruments under our strict command, we remain largely convinced that technology can lead us to greater freedom rather than into slavery. However, a possibility exists that we could be gravely mistaken.

Heidegger believes that we are blind and misled about the true nature of our reality. He completely rejects all conventional approaches to technology and freedom. Upholding a neutral view of technology and assuming we can control it is not only naïve, but also hubristic, he claims, adding that true freedom is neither negative, nor positive, nor a mastery. To alter the perspective of inquiry into these phenomena, Heidegger employs an ontological approach that grounds the essence of technology and 
freedom in humankind's relationship with Being. His unique ontology moves the description of technology away from an instrumental and deterministic standpoint and redefines freedom in terms of human participation in the revelation of truth within the context of our role as Dasein.

Understood as a process of rearranging the world into a standingreserve for indiscriminate exploitation and disposal, the essence of technology manifested by Enframing poses a looming threat to human freedom: it diminishes the immediacy of our involvement in the revelation of Being in the world. It also establishes a worldview where humans may be reduced to standing-reserve and utilized by categorical Enframing as a disposable resource. Heidegger cautions that Enframing may enslave us by posing as the only alternative to our perception of reality, and through the demise of our freedom, force humankind to seek alternatives to technological thinking-leading us eventually back unto the path to Being. However, a technological downfall is not predetermined; we are capable of realizing the true nature of Enframing and choose to establish a free relationship with technology before we are forced into a struggle to regain our freedom.

Through deliberate contemplation and a non-dominant approach to nature and technology, we may develop within us sufficient detachment and caring that would permit the handling of technology without falling under the power of its essence. It is within the realm of our free choice to consciously 
deny the determinism of Enframing while accepting our destiny as Dasein. But we must learn to live in this world without believing that we are of this world, for the essence of humankind - the essence of our Being-is otherworldly. We must halt the madness of pursuing technological progress at all cost, reflect upon our approach to one another and nature, and gaze upon the world as seekers and revealers of truth. We are not strictly limited to being owners and users of technological tools.

Heidegger insists the essence of technology, while ubiquitous and seemingly all-powerful, is not the destiny of humankind. While the danger of technology rests in the fact that it can deprive us of our freedom, it also carries the saving power that may emerge once we realize the price of blindly following the dictates of Enframing. However, Heidegger claims it is never too late to return to our dignified role as Dasein and reconnect with our destiny. Although it may not be apparent, Being requires our willingness and assistance in revealing the truth in the world. Turning away from our destiny will eventually lead us into false convictions, complacency, and hubris under the sway of the essence of technology, which is concealing the path to unconcealment, our way toward Being.

Sadly, technology may also offer us a very convincing sense of freedom and lead humankind to utter self-gratification. Perhaps one day we will become most delighted to chase after shadows, remembering nothing of our true destiny. If Enframing becomes the only lens through which we 
view reality and our perception of the world becomes mediated by technological instruments, we shall transcend the essence of humanity. We will then become content and deem we have attained the highest freedom. Convinced that everything is as it should be, nothing will appear greater than the world surrounding us-which we will be proud to have created through our self-determination. Being will no longer captivate our awe. Perhaps at that moment in time we shall overlook Prometheus to venerate the everlasting endeavor of Sisyphus, as Camus envisions:

[Sisyphus], too, concludes that all is well. This universe henceforth without a master seems to him neither sterile nor futile. Each atom of that stone, each mineral flake of that night-filled mountain, in itself forms a world. The struggle itself toward the heights is enough to fill a man's heart. One must imagine Sisyphus happy. (Camus 119)

We may also find fulfillment in the incessant pursuit of technology, but then, according to Heidegger, we shall never taste true freedom. 


\section{WORK CITED}

Arendt, Hannah. The Human Condition. Chicago: The University of Chicago Press, 1998.

Babich, Babette. "The Essence of Questioning After Technology: Techne as Constraint and the Saving Power." British Journal of Phenomenology 30/1 (January 1999): 106-124.

Barber, Katherine, ed. The Canadian Oxford Dictionary. Oxford: Oxford University Press, 1998.

Camus, Albert. The Myth of Sisyphus. London: Penguin Books, 2005.

Darby, Tom. "On Spirituals Crisis, Globalization, and Planetary Rule." Faith, Reason, and Political Life Today. Ed. Peter Augustine Lawler and Dale McConkey. Lanham: Lexington Books, 2001. 35-65.

Feenberg, Andrew. Heidegger and Marcuse: The Capture and Redemption of History. New York: Routledge, 2005.

Godzinski, Ronald. "Framing Heidegger's Philosophy of Technology." Essays in Philosophy: A Biannual Journal 6, no.1 (January 2005): 10 January 2008. $<$ <ttp://www.humboldt.edu/ essays/godzinski.html>.

Gorniak-Kocikowska, Krystyna. "The Concept of Freedom in Jaspers and Heidegger." Ed. Alan M. Olson. Heidegger and Jaspers. Philadelphia: Temple University Press, 1994. 139-152.

Heidegger, Martin. The Question Concerning Technology and Other Essays. New York: Harper, 1977. 
---. The Essence of Human Freedom: An Introduction to Philosophy. London: Continuum, 2002.

---. Basic Writings. Ed. David Farrell Krell. New York: Harper, 1993.

Henley, Wiliam E. Invictus.10 January 2008.

$<$ http://www.ocf.berkeley.edu/ aathavan/poems/INVICTUSWilliam\%20E_\%20Henley.htm>.

Hobbes, Thomas. Leviathan. London: Penguin Books, 1985.

Nietzsche, Friedrich. Beyond Good and Evil: Prelude to a Philosophy of the Future. New York: Vintage Books, 1989.

---. The Portable Nietzsche. Ed. Walter Kaufmann. New York: Penguin Books, 1976.

Pattison, George. The Later Heidegger. New York: Routledge Philosophy GuideBooks, 2000.

Rojcewicz, Richard. The Gods and Technology: A Reading of Heidegger. Albany: State University of New York Press, 2006.

Rousseau, Jean-Jacques. On The Social Contract with Geneva Manuscript and Political Economy. Ed. Roger D. Masters. Boston: Bedford/St. Martin's, 1978.

Schelling, F. W. J. Philosophical Investigation into the Essence of Human Freedom. Albany: State University of New York Press, 2006.

Schreiber, Matthew. The Question Concerning Heidegger's Critique of Subjectivity: Reflection on the Essence of Science, Technology, and the Modern Age. 10 January 2008. <http://www.earlham.edu/ phil/thesis-schreiber.html>. 
Steiner, George. Heidegger. Ed. Frank Kermode. Glasgow: Fontana, 1978.

Thiele, Leslie Paul. Timely Meditations: Martin Heidegger and Postmodern Politics. Princeton: Princeton University Press, 1995.

Thomson, lain D. Heidegger on Ontotheology: Technology and the Politics of Education. New York: Cambridge University Press, 2005.

Young, Julian. Heidegger's Later Phillosophy. Cambridge: Cambridge University Press, 2002. 